\title{
noeM, a New Nodulation Gene Involved in the Biosynthesis of Nod Factors with an Open-Chain Oxidized Terminal Residue and in the Symbiosis with Mimosa pudica
}

\author{
Benoit Daubech, ${ }^{1}$ Verena Poinsot, ${ }^{2}$ Agnieszka Klonowska, ${ }^{3}$ Delphine Capela, ${ }^{1}$ Clémence Chaintreuil, ${ }^{4}$ \\ Lionel Moulin, ${ }^{3}$ Marta Marchetti, ${ }^{1}$ and Catherine Masson-Boivin ${ }^{1,+}$ \\ ${ }^{1}$ LIPM, Université de Toulouse, INRA, CNRS, Castanet-Tolosan, France \\ ${ }^{2}$ Université de Toulouse 3, UPS CNRS 5623, UMR, Lab IMRCP, F-31062 Toulouse, France \\ ${ }^{3}$ IRD, CIRAD, Université Montpellier, IPME, Montpellier, France \\ ${ }^{4}$ Université Montpellier, CIRAD, INRA, IRD, Montpellier SupAgro, LSTM, Montpellier, France
}

Accepted 28 July 2019.

\begin{abstract}
The $\beta$-rhizobium Cupriavidus taiwanensis is a nitrogen-fixing symbiont of Mimosa pudica. Nod factors produced by this species were previously found to be pentameric chitin-oligomers carrying common C18:1 or C16:0 fatty acyl chains, $N$-methylated and C-6 carbamoylated on the nonreducing terminal $\mathrm{N}$-acetylglucosamine and sulfated on the reducing terminal residue. Here, we report that, in addition, $C$. taiwanensis LMG19424 produces molecules where the reducing sugar is open and oxidized. We identified a novel nodulation gene located on the symbiotic plasmid pRalta, called noeM, which is involved in this atypical Nod factor structure. noeM encodes a transmembrane protein bearing a fatty acid hydroxylase domain. This gene is expressed during symbiosis with $M$. pudica and requires NodD and luteolin for optimal expression. The closest noe $M$ homologs formed a separate phylogenetic clade containing rhizobial genes only, which are located on symbiosis plasmids downstream from a nod box. Corresponding proteins, referred to as NoeM, may have specialized in symbiosis via the connection to the nodulation pathway and the spread in rhizobia. noeM was mostly found in isolates of the Mimoseae tribe, and specifically detected in all tested strains able to nodulate $M$. pudica. A noeM deletion mutant of $C$. taiwanensis was affected for the nodulation of $M$. pudica, confirming the role of noeM in the symbiosis with this legume.
\end{abstract}

Keywords: Cupriavidus taiwanensis, host specificity, Mimosa pudica, Nod factors, nodulation, rhizobium-legume symbiosis

${ }^{\dagger}$ Corresponding author: C. Masson-Boivin; catherine.masson@inra.fr

Funding: This work was supported by funds from the French National Research Agency (ANR-16-CE20-0011-01) and the French Laboratory of Excellence project "TULIP" (ANR-10-LABX-41; ANR-11-IDEX-000202). B. Daubech was supported by an INRA-Région Occitanie fellowship.

*The $\boldsymbol{e}$-Xtra logo stands for "electronic extra" and indicates that six supplementary figures and three supplementary tables are published online.

The author(s) declare no conflict of interest.

() 2019 The American Phytopathological Society
Soil bacteria collectively referred to as rhizobia are able to form nitrogen-fixing symbioses with leguminous plants. These symbioses are manifested by the formation of novel root (or occasionally stem) organs called nodules, within which bacteria are internalized and fix nitrogen to the benefit of the plant. Most of the rhizobia achieve nodulation by using the so-called Nod strategy, although two alternative strategies-the type three secretion system (T3SS) and the genetically uncharacterized non Nod/non-T3SS strategies - have been identified (MassonBoivin and Sachs 2018). In the Nod strategy, host plants excrete inducing compounds - mainly flavonoids - that activate LysRtype transcriptional regulator NodD proteins of compatible rhizobia (Mulligan and Long 1985; Nelson and Sadowsky 2015). NodD proteins bind to conserved regulatory DNA sequences, termed nod boxes, which are located in the promoters of nodulation (nod) genes (Rostas et al. 1986), resulting in their transcriptional activation. Flavonoids binding to NodD enhance nod gene expression (Chen et al. 2005; Peck et al. 2006). The nod genes encode enzymes that synthesize signaling lipo-chitooligosaccharides (LCOs) called Nod factors (NFs) (Downie 1998) that are perceived by plant receptors (Broghammer et al. 2012; Madsen et al. 2003) and activate a host genetic program governing the nodulation and infection processes (Gough and Cullimore 2011; Oldroyd et al. 2011). NFs are chitin oligomers of $\beta$ - $(1,4)$-linked N-acetyl-Dglucosaminyl (GlcNAc) residues (two to six units) that are Nacylated on their nonreducing end (D'Haeze and Holsters 2002). The NF structure differs in the number of GlcNAc residues of the chitin oligosaccharide backbone - generally three, four, or fivein the nature of the fatty acyl group and in the substituents at the-generally terminal-residues. A given strain often produces a variety of NF compounds. These structural variations, which are strain or species specific, are involved in host specificity (Lerouge et al. 1990; Schultze et al. 1992) together with the range of flavonoids excreted by the plant (Liu and Murray 2016). The core lipo-chitinoligosaccharidic NF structure is encoded by the common nodABC genes, while other nod, nol, or noe genes encode modifications of this structure (Perret et al. 2000). The essential nod genes are clustered together with nitrogen-fixation genes in mobile genetic elements (MGE) such as symbiotic plasmids or genomic islands. During evolution, these symbiotic MGE have spread to different species, converting soil bacteria into mutualistic symbionts of legumes (Nandasena et al. 2006; 
Sullivan et al. 1995), a process that can be partly or fully reproduced in the lab (Marchetti et al. 2010, 2014; Sullivan and Ronson 1998). Consequently, extant rhizobia are phylogenetically diverse bacteria that belong to hundreds of species distributed in at least 14 genera of $\alpha$ - and $\beta$-proteobacteria, referred to as $\alpha$ - and $\beta$-rhizobia (Remigi et al. 2016).

The $\beta$-rhizobium Cupriavidus taiwanensis LMG19424 is a specific symbiont of Mimosa spp., including Mimosa pudica (Chen et al. 2003b). C. taiwanensis enters M. pudica roots via
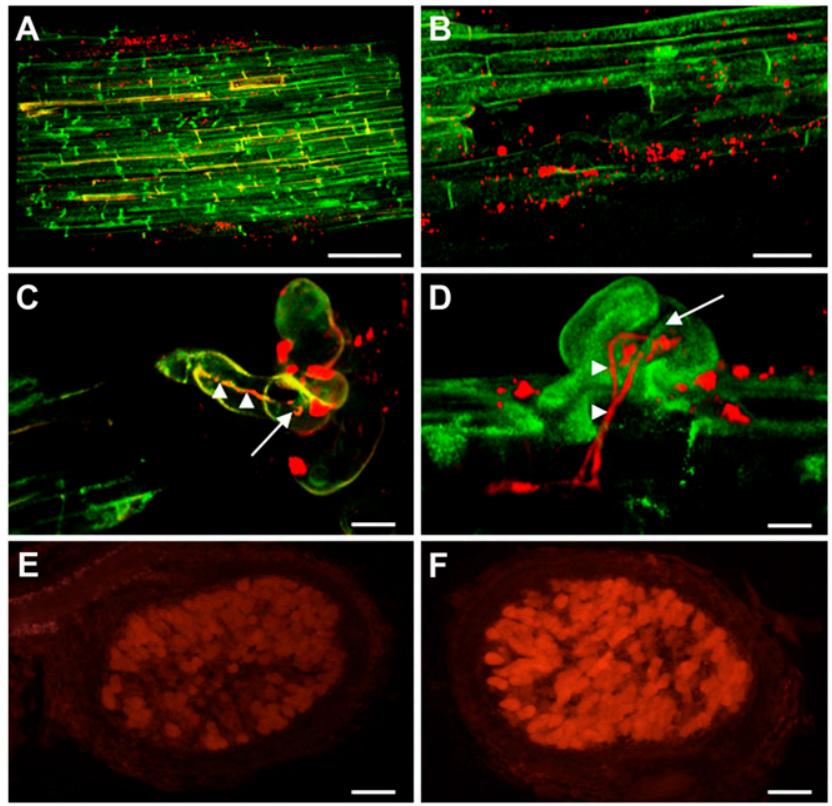

Fig. 1. noeM expression during symbiosis. Imaging of Mimosa pudica plants inoculated with Cupriavidus taiwanensis bearing a chromosomal $\mathbf{A}$, $\mathbf{C}$, and E, PpsbA-mCherry or B, D, and $\mathbf{F}$, PnoeM-mCherry fusion at $\mathbf{A}$ and $\mathbf{B}, 24$; $\mathbf{C}$ and $\mathbf{D}, 7$; or $\mathbf{E}$ and $\mathbf{F}, 21$ days postinoculation. Red indicates mCherry, green indicates autofluorescence of plant cells, arrow indicates infection site, and arrowhead indicates infection thread. Scale bars: $100 \mu \mathrm{m}$ $(\mathrm{A}, \mathrm{B}, \mathrm{E}$, and $\mathrm{F})$ and $10 \mu \mathrm{m}(\mathrm{C}$ and $\mathrm{D})$.

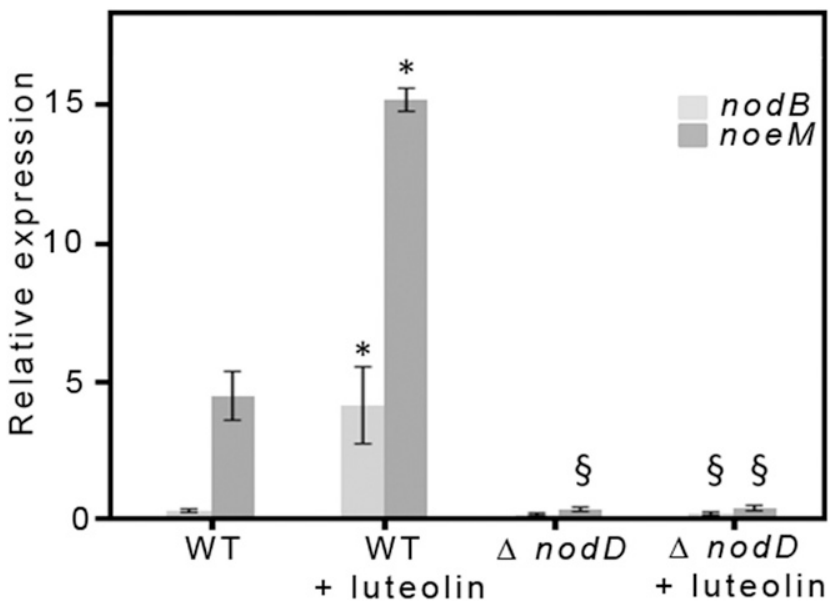

Fig. 2. Relative expression of the nodB and noeM genes in wild-type (WT) and mutant $(\Delta$ nodD $)$ strains of Cupriavidus taiwanensis. Strains were cultivated in minimal medium with or without $10 \mu \mathrm{M}$ luteolin. The expression of $n o d B$ and noe $M$ were quantified by quantitative PCR $5 \mathrm{~h} 30 \mathrm{~min}$ after luteolin induction. Raw expression levels were normalized by the hisB and rpoA gene expressions. Symbols: $*$ indicates statistically significant difference between the treatment with or without luteolin for the same strain $(P<0.05$, Student's $t$ test with paired data) and $\S$ indicates statistically significant difference between the WT and mutant strain for the same treatment $(P<0.05$, Student's $t$ test with paired data). infection threads that ultimately release bacteria into nodule cells, where bacteroids are not terminally differentiated (Marchetti et al. 2011). Genome sequencing revealed that this strain possesses a large symbiotic plasmid, pRalta, harboring one nod locus (Amadou et al. 2008). This locus contains a nodBCIJHASUQ operon preceded by a nod box (nod box 1) as well as one $\operatorname{nod} D$ gene divergently transcribed. NFs produced by $C$. taiwanensis were found to be pentameric chitin-oligomers and $\mathrm{N}$-acylated by vaccenic acid (C18:1) or palmitic acid (C16: 0 ) on their nonreducing end (Amadou et al. 2008). Consistent with the presence of nodU, nodS, and nodH that are responsible for the addition of O-carbamoyl, N-methyl, and sulfate (S) groups, respectively, on the core NF, most of the molecules are sulfated at the reducing end and substituted by an N-methyl and a carbamoyl group at the terminal nonreducing sugar. A second nod box (nod box2) has been predicted $92 \mathrm{~kb}$ from the nod locus (Amadou et al. 2008). This nod box is upstream from a single gene, pRalta_0471, that has been annotated as a fatty acid hydrolase. This gene was found in all sequenced C. taiwanensis strains (Clerissi et al. 2018) and to have ortho$\operatorname{logs}$ in other recently sequenced $M$. pudica symbionts, Paraburkholderia phymatum STM815 (BURPHP2_0638), and Rhizobium mesoamericanum STM3625 (BN77v2_p2140043) (Moulin et al. 2013, 2014). It has been shown to be induced by M. pudica exudates in all three species (Klonowska et al. 2018).

In this study, we characterize pRalta_0471, which we renamed noeM. We show that noeM is involved in the synthesis of atypical NF molecules and plays a role in the nodulation of $M$. pudica. The phylogenetic distribution of noeM supports its role in the symbiosis with Mimosa spp.

\section{RESULTS}

noeM is expressed during symbiosis and requires NodD and luteolin for optimal expression.

To analyze noeM regulation, we monitored the expression of $C$. taiwanensis noeM ( $p$ Ralta_0471) in both free-living and symbiotic conditions. For that, we constructed a chromosomic noeM-mCherry fusion in C. taiwanensis CBM832, a streptomycin-resistant derivative of the wild-type LMG19424 strain. This was done by cloning a 404-bp fragment containing nod box 2 upstream noeM fused to the mCherry gene at the $\operatorname{glmS}$ intergenic region of CBM832. Chromosomic mCherry fusions with the promoters of the nitrogen-fixation nifH and the constitutively expressed chloroplastic $p s b A(P p s)$ genes were used as controls.

To check whether noeM is expressed during the symbiotic process, seedlings of $M$. pudica were single inoculated with CBM832 bearing either the noeM, psbA, or nifH promoter fusion. Plants were harvested at different time points after inoculation and examined using confocal laser microscopy and light microscopy. Unlike nifH, which is only expressed in nodule cells (Marchetti et al. 2011), noeM was expressed at a level similar to that of the constitutively expressed $p s b A$ gene at all stages of symbiosis (i.e., in the rhizosphere, in the infection sites, in the infection threads, and within bacteroids) (Fig. 1).

The nod genes of $C$. taiwanensis were shown to be induced by the flavonoid luteolin (Amadou et al. 2008), likely through the activation of the single nodD regulatory gene identified in the LMG19424 genome. To analyze the effect of luteolin and nodD on noe $M$ expression in vitro, we constructed a nodD deletion mutant of the CBM832 strain carrying the noeMmCherry fusion. The expression of noeM and nodB in CBM832 and CBM832 $\triangle$ nodD was first measured by quantitative reverse-transcription (RT)-PCR in cultures grown in minimal medium with or without luteolin $(10 \mu \mathrm{M})$ for $5 \mathrm{~h} 30 \mathrm{~min}$ (Fig. 2). The expression of nodB and noeM increased by a factor of 
approximately 14.5 and 3.4 , respectively, in the presence of luteolin. No or very weak expression was measured in the CBM832 $\triangle$ nodD background. In addition, we monitored the expression of noeM in CBM832 and CBM832 4 nodD grown in microplates in minimal medium with or without luteolin by measuring the optical density (OD) and mCherry fluorescence of the cultures over $24 \mathrm{~h}$ (Supplementary Fig. S1). In the absence of luteolin, the kinetics of noeM expression was similar to that of the constitutively expressed $p s b A$ fusion, although weaker. Its expression started increasing $5 \mathrm{~h}$ after medium inoculation and reached a plateau at approximately $17 \mathrm{~h}$. noeM expression was significantly higher in the presence of luteolin from time $=17 \mathrm{~h}$. By contrast, noe $M$ was weakly expressed in a $\Delta$ nodD background, although higher than nifH expression, whatever the presence of luteolin.

Altogether, these data indicated that noe $M$ was induced by luteolin, the inducer of nod genes in C. taiwanensis, and requires NodD for basal and luteolin-induced expression.

\section{noeM is involved in NF biosynthesis.}

Because noe $M$ is predicted to belong to the fatty acid hydroxylase family of genes, we investigated the possibility that noeM is involved in the synthesis of an additional NF moleculepossibly by modifying the NF lipid moiety-that has been missed in the previous study of $C$. taiwanensis NFs (Amadou et al. 2008).

We first reanalyzed NFs produced by $C$. taiwanensis LMG19424 and its streptomycin-resistant derivative CBM832 in response to luteolin activation, taking advantage of technical advances in mass spectrometry (MS) technology that allow an increased sensitivity of the online liquid chromatography tandem mass spectrometry (MS/MS) coupling. Ultrahigh-performance liquid chromatography (UPLC)-QTrap-enhanced MS in the positive mode analyses showed that, in addition to the already identified compounds (Fig. 3A), the strains produce NF molecules that were not described before. Enhanced product ion scan MS/MS experiments in the positive mode were performed on the two major compounds, $\mathrm{m} / \mathrm{z}$ 1,393.6 (formerly described) and $\mathrm{m} / \mathrm{z}$ 1,423.7 (the undescribed one) (Fig. 4A). The MS/MS spectra recorded for these two compounds exhibited the same fragmentation pattern (the same B1, B2, B3, and B4) (Supplementary Fig. S2). This clearly indicated that the modification producing the mass shift of 30 atomic mass units (amu) (1,423 to 1,393) specifically affects the fifth GlcNAc ("reducing-end"), while it still carries an $\mathrm{S}$ group.

Only a few sugar modifications result in a mass difference of 30 amu: addition of a $\mathrm{CH}_{2} \mathrm{O}$ group or addition of two oxygen with loss of two hydrogen $(+2 \mathrm{O}-2 \mathrm{H}$ atoms $)$. To determine which modification is involved, the NF fractions were submitted to Fourier-transform ion cyclotron resonance MS/MS analyses in the positive and in the negative electrospray ionization (ESI) modes (resolution of 195,000). The major member of the new family exhibited an exact mass of $1,421.5857$. The mass default $(0.5857)$ and the isotopic profile $(M+1=67 \%)$ were compatible with the NF generic structure. The MS/MS fragmentation pattern obtained in the negative mode indicated clearly the loss of $\mathrm{CO}_{2}(-43.99 \mathrm{amu})$ starting from the molecular ion 1,421.59. The high-resolution $\mathrm{m} / \mathrm{z}$ values of the molecular ions of the classical $(1,391.6115)$ and the novel $(1,421.5857)$ structures were compared. The exact mass difference was 29.974 amu between the two NF series. The gain of a $\mathrm{CH}_{2} \mathrm{O}$ would result in a mass difference of $30.011 \mathrm{amu}$. The gain of two $\mathrm{O}$ associated with the loss of two $\mathrm{H}$ would result in a difference of $29.988 \mathrm{amu}$. With a resolution of 195,000, the third decimal is significant at a mass of $30 \mathrm{amu}$. Therefore, the modification here observed on the classical NF structure is an oxidation of the terminal sugar unit. To explain this $+2 \mathrm{O}-2 \mathrm{H}$, the only possibility is that the reducing sugar is open and oxidized into a diacid. This implies that the $\mathrm{S}$ group located on the O-6 for the common structure has to migrate to the neighbor O-5. The presence of the carboxylic groups explains the loss of $\mathrm{CO}_{2}$ observed on the MS/MS spectrum.

To assess the presence of the carboxylic groups, we esterified the sample with diazomethane and reanalyzed them by ESI MS/MS. The new characterized NF-like molecules were demonstrated as esterified twice with diazomethane. This confirmed the presence of two free carboxylic acids $(\mathrm{m} / \mathrm{z}$ 1,437.6 and $\mathrm{m} / \mathrm{z} 1,451.7)$.

Yet, the arrangement of these chemical groups (i.e., two $\mathrm{COOH}$, one $\mathrm{N}$-acetyl, and one $\mathrm{SO}_{3} \mathrm{H}$ ) remained hypothetical. We were not able to write any alternative formula other than a lipochito-tetramer decorated with a sulfated, dehydroxylated, and $\mathrm{N}$-acetylated adipic side chain (LCO-V open-chain oxidized) (Fig. 3B). The newly described NF (MW 1,422.6) is a member of a family that corresponds well to the classic family. The structural variations mostly affected the lipid chain and the presence of the carbamoyl group (LCO-V open-chain oxidized C18:1/C18:0/C16:0, NMe/H, Cb/H, and S) (Fig. 3B; Table 1; Supplementary Table S1). In both NF molecules, the classical and open-oxidized ones, the acyl chain was mainly a $\mathrm{C} 18: 1$, the $\mathrm{C} 18: 0$ and $\mathrm{C} 16: 0$ being present in less than 10\% of the molecules. The percentage of open-chain oxidized structures in total C. taiwanensis NF compounds varied from 38 to $77 \%$ in our culture conditions (Table 1).

We constructed an noeM deletion mutant of CBM832, and determined the structure of the NFs it produced. NFs secreted by CBM832 2 noe $M$ were found to bear the same acyl groups as
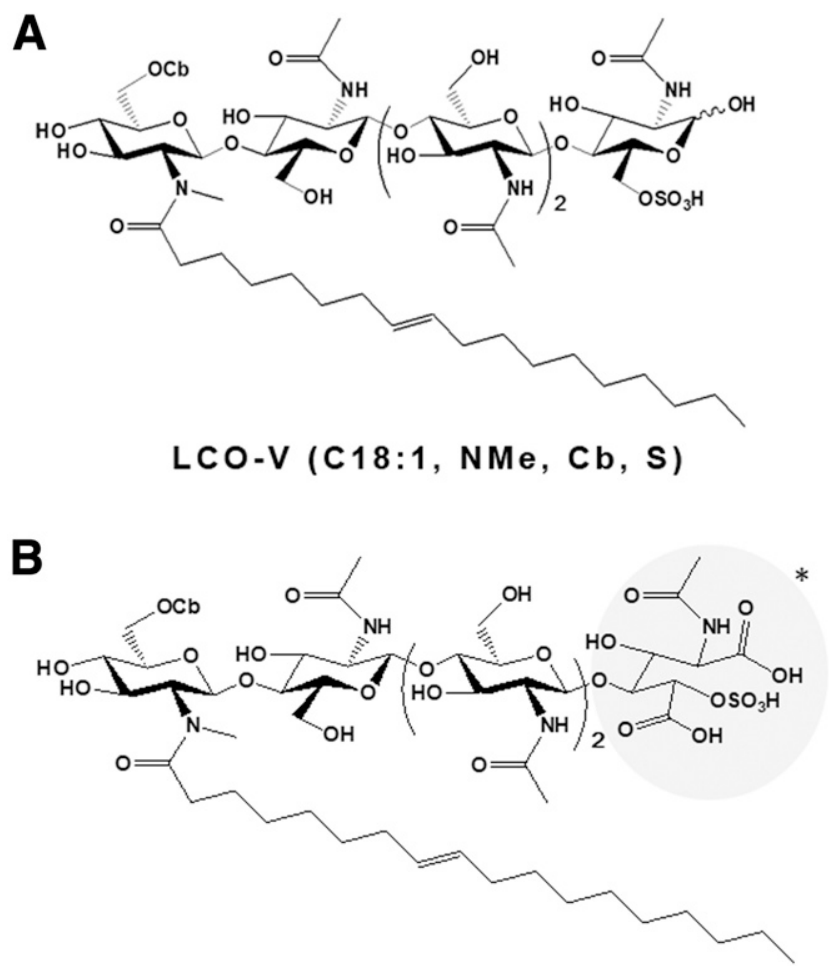

LCO-V open-oxidized (C18:1, NMe, Cb, S)

Fig. 3. Chemical structure of main Nod factors produced by Cupriavidus taiwanensis. A, Molecules previously identified and B, molecules newly identified in this study. LCO = lipo-chitooligosaccharide. An asterisk (*) indicates the open-oxidized terminal residue, where the position of the two $\mathrm{COOH}$, the N-acetyl, and the $\mathrm{SO}_{3} \mathrm{H}$ groups is hypothetical. In $10 \%$ of the classical or open-oxidized molecules, the $\mathrm{C} 18: 1$ acyl chain is replaced by a C18:0 or C16:0 group and the carbamoyl or N-Me can be absent. 
the wild-type strain. However, CBM832 4 noe $M$ only produced the usual LCO-V (C18:1/C18:0/C16:0, NMe/H, Cb/H, and S) structure when the open oxidized family is completely absent (Fig. 4B; Table 1). The complementation of CBM832 4 noeM with the original noeM gene restored the production of LCO-V open-chain oxidized (C18:1/C18:0/C16:0, $\mathrm{NMe} / \mathrm{H}, \mathrm{Cb} / \mathrm{H}$, and $\mathrm{S})$ molecules (Table 1). To confirm the role of noeM using another genomic background, we introduced the wild-type or the noeM-deleted pRalta in $R$. solanacearum GMI1000 and analyzed the NFs of the two strains. GMI1000pRalta produced both classical and open-chain oxidized LCO-V structures, while GMI1000pRalta $\triangle$ noe $M$ produced only the classical structure (Table 1). This indicated that noeM is a nod gene involved in the biosynthesis of an atypical NF structure.

noeM has specialized in rhizobial symbiosis.

To analyze the phylodistribution of noeM, we searched for homologs of pRalta_0471 in data banks. We retrieved 78 different NoeM homologs originating from 136 different strains belonging to $\alpha$ - and $\beta$-proteobacteria (Supplementary Table

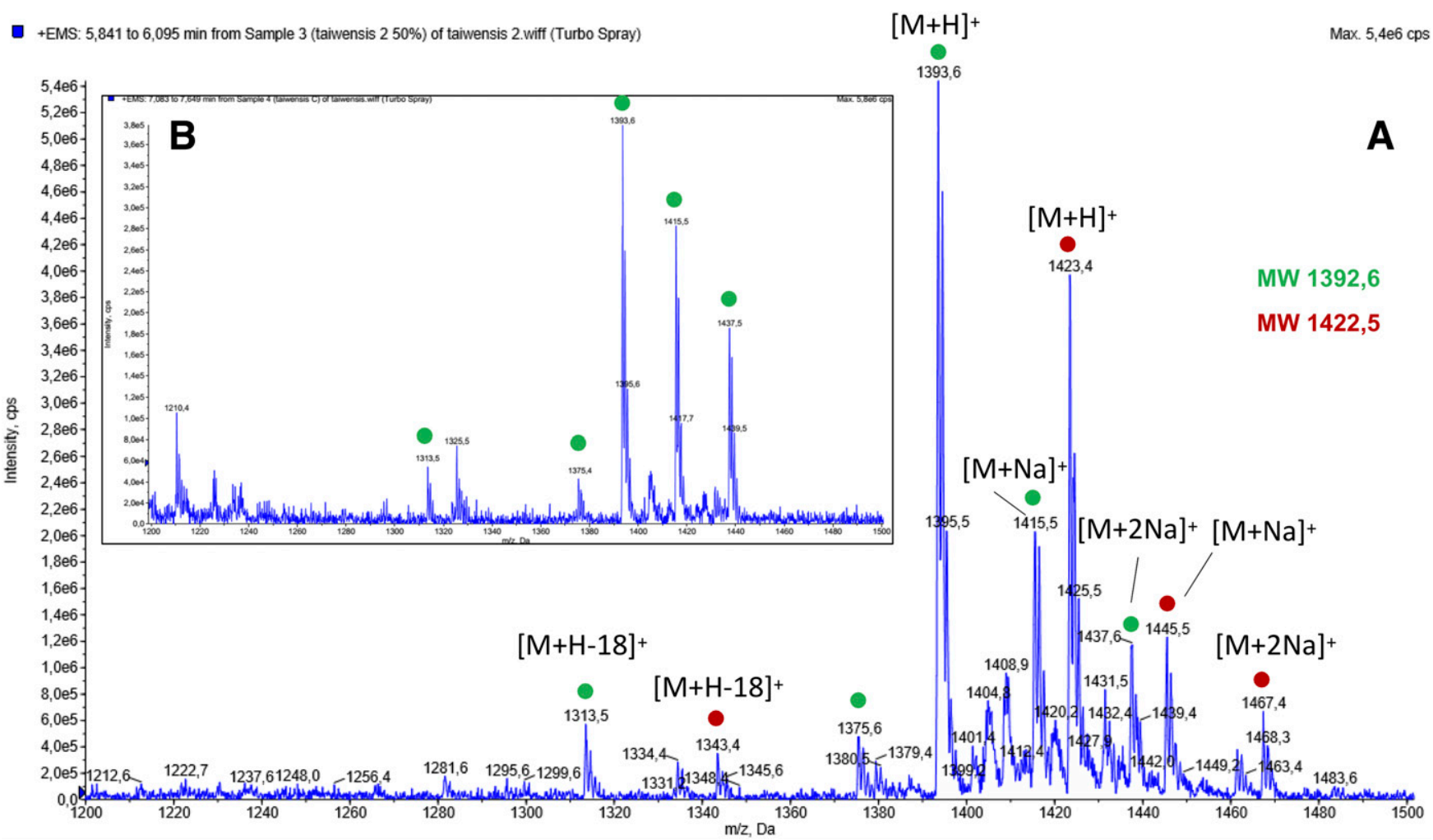

Fig. 4. Ultrahigh-performance liquid chromatography (UPLC) mass spectrometry spectra of Cupriavidus taiwanensis Nod factors (NFs). The reversed-phase SPE fraction eluting with $50 \%$ acetonitrile was subjected to tandem mass spectrometry analysis on a Q-Trap4500 system coupled with a UPLC devise. The spectrum presented is the sum of the spectra obtained over the NF retention time domain. Even under strong acidic UPLC conditions, the presence of sodium adducts was dominant (e.g., $\mathrm{MH}+$ at m/z 1,393 with $\mathrm{MNa}+$ at $\mathrm{m} / \mathrm{z}$ 1,415 and $\mathrm{M}(\mathrm{Na}) 2+$ at m/z 1,437 or 1,423.7 with 1,445.7 and 1,467.7, respectively). A, For the LMG19424 and its streptomycin-resistant derivative CBM832, two compound families were observed. B, For the deletion mutant CBM832 $\Delta$ noeM, only the usual NFs were detected.

Table 1. Summary of mass spectrometer analyses ${ }^{\mathrm{a}}$

\begin{tabular}{|c|c|c|c|c|c|}
\hline $\operatorname{Exp}$ & Species & Strain & OD & $\begin{array}{l}\text { Quantity LCO-V } \\
\text { (counts/scan) }\end{array}$ & $\begin{array}{c}\text { Quantity LCO redox } \\
\text { (counts/scan) }\end{array}$ \\
\hline 1 & Cupriavidus taiwanensis & LMG19424 & 0.881 & $2.92 \mathrm{e}^{6}$ & $8.50 \mathrm{e}^{6}$ \\
\hline 1 & C. taiwanensis & CBM832 & 0.678 & $6.50 \mathrm{e}^{6}$ & $3.99 \mathrm{e}^{6}$ \\
\hline 2 & C. taiwanensis & CBM832 & 0.8 & $3.25 \mathrm{e}^{6}$ & $2.70 \mathrm{e}^{6}$ \\
\hline 3 & C. taiwanensis & CBM832 & 0.71 & $2.00 \mathrm{e}^{6}$ & $6.80 \mathrm{e}^{6}$ \\
\hline 4 & C. taiwanensis & CBM832 & 0.918 & $26.00 \mathrm{e}^{6}$ & $18.00 \mathrm{e}^{6}$ \\
\hline 5 & C. taiwanensis & CBM8324nоем & 0.8 & $3.00 \mathrm{e}^{6}$ & 0 \\
\hline 6 & C. taiwanensis & CBM8324nоем & 0.27 & $0.57 \mathrm{e}^{6}$ & 0 \\
\hline 7 & C. taiwanensis & CBM832Anоем & 0.996 & $2.00 \mathrm{e}^{6}$ & 0 \\
\hline 3 & C. taiwanensis & CBM832यnоем & 0.668 & $12.60 \mathrm{e}^{6}$ & 0 \\
\hline 4 & C. taiwanensis & CBM8324nоеM::поем & 0.842 & $21.40 \mathrm{e}^{6}$ & $12.40 \mathrm{e}^{6}$ \\
\hline 4 & C. taiwanensis & CBM8324 поеM::поем & 0.991 & $22.50 \mathrm{e}^{6}$ & $15.00 \mathrm{e}^{6}$ \\
\hline 8 & Rhizobium solanacearum & GMI1000pRalta & 0.443 & $17.2 \mathrm{e}^{6}$ & $8.40 \mathrm{e}^{6}$ \\
\hline 9 & $R$. solanacearum & GMI1000pRalta & 0.599 & $5.30 \mathrm{e}^{6}$ & $10.20 \mathrm{e}^{6}$ \\
\hline 9 & $R$. solanacearum & GMI1000pRalta $\Delta$ nоем & 0.52 & $0.74 \mathrm{e}^{6}$ & 0 \\
\hline 9 & $R$. solanacearum & GMI1000pRalta $\Delta$ noeM & 0.546 & $0.93 \mathrm{e}^{6}$ & 0 \\
\hline
\end{tabular}

${ }^{\text {a }}$ Nod factors produced by $C$. taiwanensis and $R$. solanacearum derivatives. OD represents the optical cell density for each culture at 600 nm. LCO $=$ lipochitooligosaccharide. Quantities are given as ion intensities on the spectra summed over 1.1 min (Nod factor domain) and recorded after injecting $2 \mu l$ of the SPE fraction dissolved in $250 \mu \mathrm{l}$ of acetonitrile/ $\mathrm{H}_{2} \mathrm{O}(1: 1)$. Independent experiments (Exp) have different numbers. 
S2). These proteins fall into two groups. The first group (group I) contained proteins exhibiting low similarity ( $\leq 44 \%$ identity in amino acid sequence, aligning $\geq 57 \%$ of the query protein). Proteins of this group are mainly from non rhizobial strains belonging to the Sphingomonas, Roseomonas, Devosia, Massilia, or Comamonas genera but are also present in some rhizobial strains ( $P$. tuberum WSM4176 and DUS833, $P$. ribeironis STM7296, and $R$. freirei PRF81). The second group (group II) contained proteins exhibiting strong similarity with pRalta_0471 ( $\geq 70 \%$ identity in amino acid sequence, aligning $\geq 76 \%$ of the query protein). All of the proteins of this group are from rhizobial strains belonging to seven genera (i.e., Ensifer) Sinorhizobium, Mesorhizobium, Neorhizobium, and Rhizobium in $\alpha$-proteobacteria and Paraburkholderia, Trinickia, and Cupriavidus in $\beta$-proteobacteria). Some strains in this group possess two copies (Trinickia symbiotica JPY366 and Paraburkholderia sp. CCGE1002 and JPY251). Group II proteins grouped into a strongly supported phylogenetic clade, clearly separated from other NoeM homologs (Fig. 5). Corresponding genes also form a separate phylogenetic clade (Supplementary Fig. S3). C. taiwanensis NoeM is predicted to be a transmembrane protein with three $\mathrm{N}$-terminal transmembrane helices and to contain a C-terminal fatty acid hydroxylase domain of 134 amino acids (IPR006694/PF04116) with one HXXXH and two HXXHH motifs involved in iron binding (Shanklin et al. 1994) (Supplementary Fig. S4). These features are highly conserved in all proteins of group II, except in strains $R$. freirei PRF81, $R$. tropici CIAT899, R. leucaenae CFN299, $R$. lusitanum P1-7, and Mesorhizobium helmanticense CSLC115N, where the NoeM homologous protein corresponds to a $3^{\prime}$ fragment of a full-length protein interrupted by a transposase, and is likely nonfunctional.

Among rhizobia possessing group II noeM homologs, 22 strains distributed in the Rhizobium, Sinorhizobium, Mesorhizobium, Paraburkholderia, and Cupriavidus genera have a complete assembled genome (Fig. 5). In all of these strains, the noeM gene is located on the symbiotic plasmid. The only exception is $M$. huakuii $7653 \mathrm{R}$, where noe $M$ is not located on the plasmid that bears the common nodABC genes but on another plasmid (pMHb), together with nodM. In all of these rhizobial strains, except in $R$. tropici CIAT899, where noeM is interrupted by a transposase, and in Paraburkholderia sp. CCGE1002 upstream from the second copy of the gene, noeM is preceded by a nod box. In these genomes, noeM is either clustered with some symbiotic genes (e.g., R. etli sv. mimosae Mim1) or away from them and framed by transposases (e.g., C. taiwanensis LMG19424), suggesting different evolutionary histories (Fig. 6).

Altogether, this showed that a class of fatty acid hydroxylases forming a separate phylogenetic clade are exclusively present in rhizobia and connected to the nod regulation. Thus, we called these genes and proteins that specialized in legume symbiosis noe $M$ and NoeM, respectively.

\section{noeM is overrepresented in Mimosa symbionts.}

Most of the rhizobial-retrieved NoeM sequences come from strains originally isolated from Mimosa spp. (48\%) or from species belonging to the Mimoseae tribe (56\%) of the Caesalpinioideae subfamily. To evaluate the link between noeM and Mimosa symbiosis, we screened our collection of Mimosa strains for the presence of noeM by PCR amplification and sequencing of an internal fragment of noeM (Table 2). We found that 22 of $35(63 \%)$ of the Mimosa strains possess an noeM gene. Phylogenetic analysis confirmed that nucleotidic sequences belong to the noeM clade. Notably, all $(n=11)$ of the Mimosa pudica strains harbored noeM, whatever their genus affiliation or geographical origin, suggesting that this gene is a feature of $M$. pudica symbionts. To explore this possibility, we analyzed strains isolated from legumes belonging to other Mimoseae genera (Anadenanthera, Piptadenia, Parapiptadenia, Prosopis, and Goldmania) or to genera from other tribes (Aspalathus, Dalbergia, and Phaseolus) for both the presence of noeM and the capacity to nodulate $M$. pudica (Table 2). We found a strong correlation between these two traits. All strains nodulating $M$. pudica (i.e. 11 Paraburkholderia strains and 1 Sinorhizobium arboris strain isolated from legumes of the Mimoseae tribe) possessed noeM. Conversely, most strains possessing noeM nodulated $M$. pudica. Exceptions were strains $R$. freirei PFR81, R. leucaenae CFN299, R. tropici CIAT899, and $R$. gallicum sv. gallicum R602 isolated from Phaseolus vulgaris; R. gallicum UPRM8060 isolated from Piptadenia flava; and S. arboris LM14917 and S. kostiense LMG19225 isolated from Prosopis chilensis, which did not nodulate $M$. pudica in the laboratory. Notably, in $R$. freirei PFR81, R. leucaenae CFN299, and $R$. tropici CIAT899, noeM is interrupted by a transposase (see above).

\section{The noeM gene of $C$. taiwanensis is involved in symbiosis with $M$. pudica.}

To evaluate the role of noeM in the symbiotic capacity of M. pudica symbionts, we constructed a deletion mutant of C. taiwanensis CBM832, a streptomycin-resistant derivative of LMG19424.

M. pudica plantlets were single inoculated with CBM832 or its noeM mutant, and their nodulation followed over 28 days. No significant difference was observed between the nodulation kinetics of $C$. taiwanensis and of its noeM mutant (Supplementary Fig. S5). To more deeply analyze the role of noeM in the $C$. taiwanensis- $M$. pudica symbiosis, $M$. pudica plantlets were coinoculated with a mixture $\left(1: 1\right.$ ratio, $5 \times 10^{5}$ total bacteria per plant) of CBM832 constitutively expressing green fluorescent protein (GFP) and CBM832 $\Delta$ noeM. Nodules were collected at 21 and 42 days postinoculation (dpi). Each nodule was individually analyzed for the presence and the quantity of each strain by plating, allowing determination of the relative in planta fitness (percentage of each strain recovered from all nodules), the nodulation competitiveness (percentage of nodules inhabited by each strain), and the nodule infection capacity of each strain (number of bacteria per nodule for each strain). The noeM mutant was much less fit in planta than the wild-type strain, because mutant bacteria represented approximately 5.61 and $12.06 \%$ of the bacteria isolated from all nodules at 21 and 42 dpi, respectively (Fig. 7A). The differential fitness was due to a lower nodulation competitiveness of CBM832 $\Delta$ noeM. This strain formed only approximately $18.94 \%$ of total nodules at 21 dpi and $14.35 \%$ at 42 dpi (Fig. 7B). Yet, the CBM832 $\Delta$ noeM capacity to infect nodules it induces seemed not to be altered, because the numbers of bacteria per nodule were found to be similar for both strains at 21 and $42 \mathrm{dpi}$ (Fig. 7C). Complementation of CBM832 2 noe $M$ with the noeM gene restored the in planta fitness and the nodulation competitiveness of the strain (Fig. 7A and B).

\section{DISCUSSION}

Bacterial nod genes play a key role in the establishment of nitrogen-fixing symbiosis by synthesizing the NF signaling compounds that trigger the plant developmental program of nodule organogenesis (Oldroyd and Downie 2008). Most NFs described to date are oligomers of $\mathrm{N}$-acetyl-D-glucosaminyl residues, $\mathrm{N}$-acylated on their nonreducing end, and substituted by various groups on their reducing or nonreducing residues (D'Haeze and Holsters 2002). A very few atypical NFs that do not follow this rule have been described. As examples, 3-O fucosylation and 3-O acetylation of the glucosamine residue 
next to the nonreducing residue were reported in Mesorhizobium loti (Olsthoorn et al. 1998) and R. galegae (Yang et al. 1999) NFs, respectively, and a glucose is inserted in the backbone of the molecule in S. fredii (Bec-Ferté et al. 1996). Here, we found that $C$. taiwanensis LMG19424 produces, in addition to the compounds previously described (Amadou et al. 2008), novel NF compounds where the reducing sugar is in the open-chain form and oxidized (Fig. 3). This terminal residue carries two carboxyl, one N-acetyl, and one S groups. Yet, the arrangement of these chemical groups as proposed in Figure $3 \mathrm{~B}$

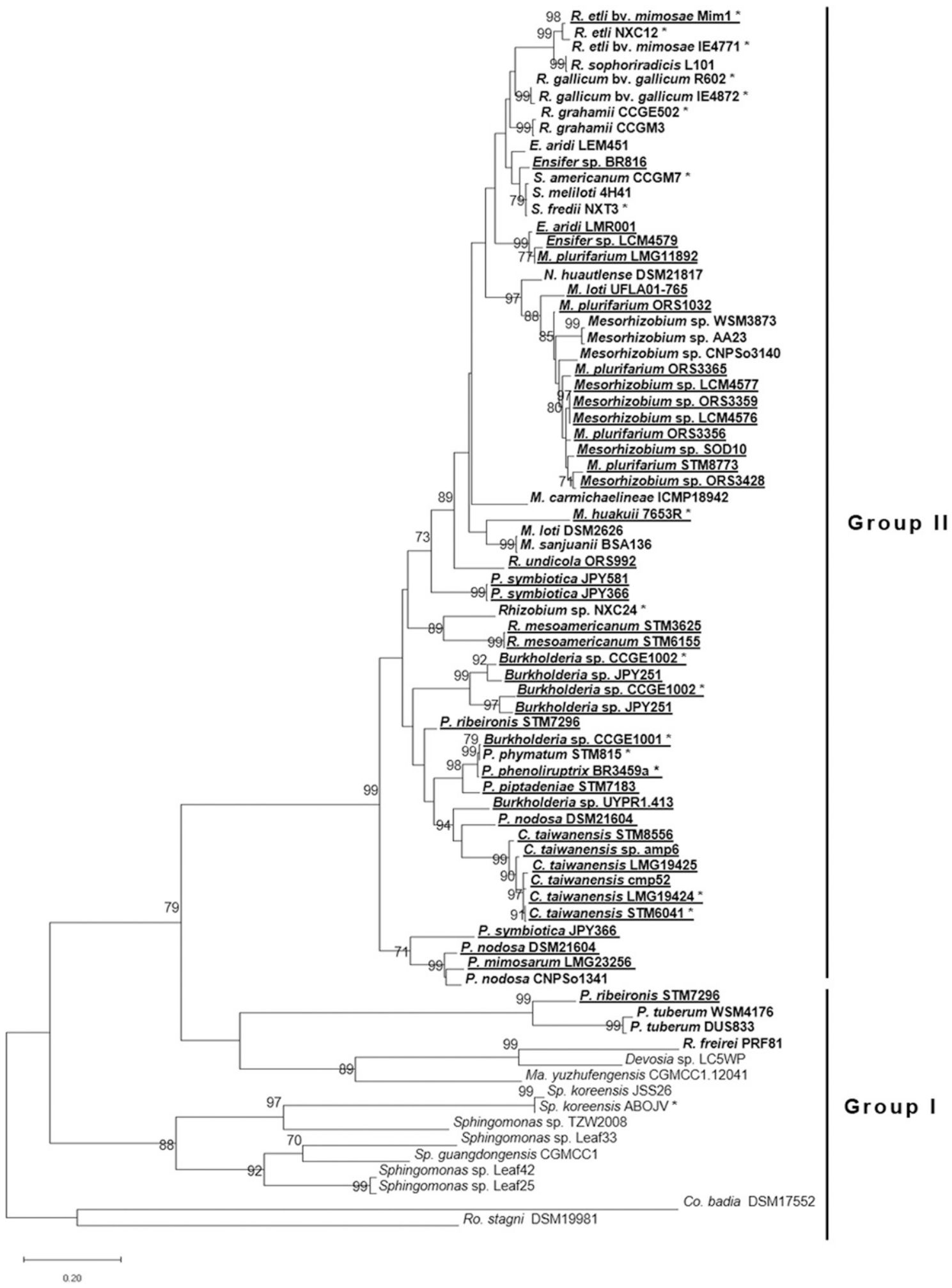

Fig. 5. Phylogenetic tree of protein sequences homologous to Cupriavidus taiwanensis NoeM. Maximum-likelihood phylogenetic tree based on 76 sequences with 626 amino acid positions inferred by the MEGA X program. Numbers at internal nodes correspond to bootstrap support values (in percentages) obtained in the analysis of 1,000 replicates using the same program and model of sequence evolution. Only bootstraps above 70 are indicated. Truncated sequences have been excluded from the analysis. Strains in bold are rhizobia, strains underlined were isolated from a plant belonging to the Mimoseae tribe, and an asterisk ( $*$ ) indicates assembled genomes. $\mathrm{C}=$ Cupriavidus, $\mathrm{Co}=$ Comamonas, $\mathrm{E}=$ Ensifer, $\mathrm{Ma}=$ Massilia, $\mathrm{M}=$ Mesorhizobium, $\mathrm{P}=$ Paraburkholderia, $\mathrm{R}=$ Rhizobium, $\mathrm{Ro}=$ Roseomonas, $\mathrm{S}=$ Sinorhizobium, and $\mathrm{Sp}=$ Sphingomonas 
remains hypothetical, because complete assignment was not possible. The presence of an open-chain terminal residue was already described for the Leucaena leucocephala symbiont Rhizobium sp. BR816 (Supplementary Fig. S6) and the Phaseolus vulgaris symbiont $R$. gallicum sv. gallicum R602, where the "reducing" residue is a sulfated glucosaminitol with a varying degree of acetylation (Snoeck et al. 2001; Soria-Diaz et al. 2006). However, the terminal residue was found reduced in strains BR816 and R602, whereas it is oxidized with two carboxyl groups in C. taiwanensis LMG19424, increasing the complexity of the structure.

We identified a gene ( $p$ Ralta_0471), which we called noeM, involved in the biosynthesis of these novel open-chain oxidized NF structures. A C. taiwanensis strain lacking this gene did not produce open-chain oxidized structures, whereas the reintroduction of noeM in this mutant restored the production of such structures. Furthermore, introduction of a wild-type or an noeMdeleted pRalta in $R$. solanacearum confirmed that C. taiwanensis NoeM is involved in the modification of the terminal residue. NoeM (275 amino acids) is predicted to belong to the fatty acid hydroxylase superfamily (IPR006694/PF04116), a group of integral membrane proteins with an oxidoreductase activity and mainly involved in lipid biosynthesis. Enzymes of this superfamily, which includes fatty acid and carotene hydroxylases as well as sterol desaturases (Kim and Oh 2013), may thus include members acting on the sugar side of liposaccharides. Rhizobium sp. BR816 and $R$. gallicum R602, which both produce NFs with an open "reducing sugar", also contain a very close NoeM homolog (76\% amino acid identity, aligning $99 \%$ of the C. taiwanensis protein). However, this terminal residue is reduced, except if open-chain oxidized structures have been missed due to early technology. Thus, we hypothesize that noeM is involved in the production of an open-chain reduced terminal residue, while another still undetermined protein or proteinspresent in C. taiwanensis - is involved in the further oxidation of this residue. Indeed, it is unlikely that a single enzyme catalyzes the two (several) steps of the LCO-V (C18:1/C16:0, NMe, Cb/H, and $\mathrm{S}$ ) modification (i.e., aldehyde reduction of a spontaneously opened reducing sugar and the oxidation of the glucosaminitol group) after the migration of the sulfate to the O-5 position.

\section{B. phymatum STM815}

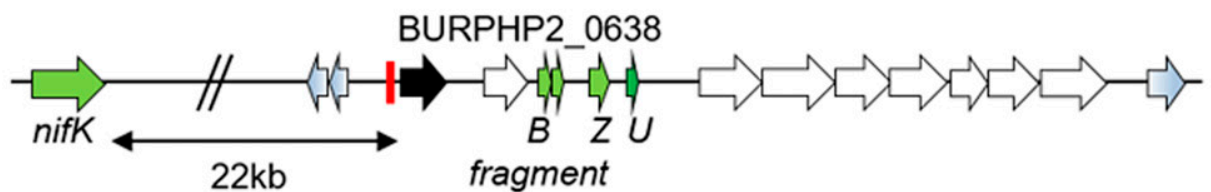

\section{C. taiwanensis LMG 19424}

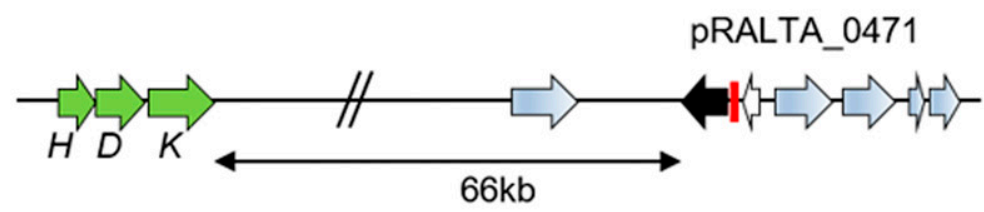

\section{R. mesoamericanum STM3625}

\section{BN77v2_p2140043}

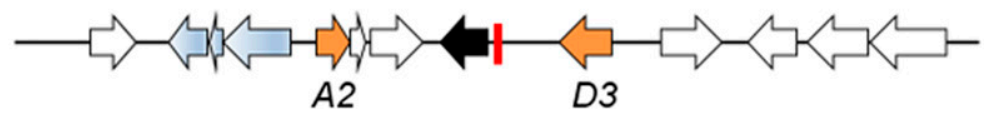

\section{R. etli bv. mimosae Mim1}

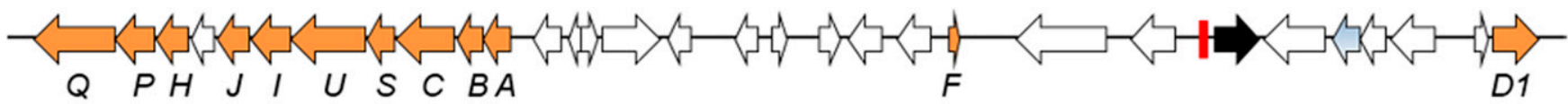

\section{R. grahamii CCGE502}

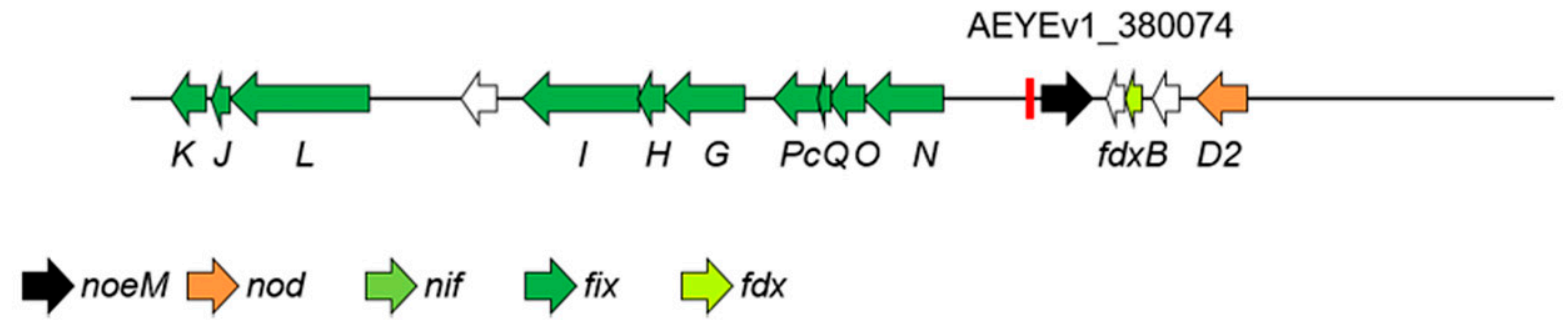

Fig. 6. Genomic context of noeM genes. Genes are represented by arrows of different colors and nod boxes are represented by red bars. Not all open reading frames are represented. Data for Rhizobium grahamii is from Althabegoiti et al. (2014). 
Table 2. Presence of noeM and nodulation of Mimosa pudica (Nod) in a collection of legume isolates ${ }^{\mathrm{a}}$

\begin{tabular}{|c|c|c|c|c|c|c|c|c|}
\hline Genus & Species & Strain & Original host plant & $\begin{array}{c}\text { Host plant } \\
\text { tribe }\end{array}$ & $\begin{array}{c}\text { Geographic } \\
\text { origin }\end{array}$ & Nod & поем & $\begin{array}{c}\text { Strain } \\
\text { source/reference }\end{array}$ \\
\hline Bradyrhizobium & sp. & STM7329 & Piptadenia paniculata & Mimoseae & Brazil & - & 0 & Bournaud et al. 2013 \\
\hline Bradyrhizobium & sp. & STM7331 & Piptadenia paniculata & Mimoseae & Brazil & - & 0 & Bournaud et al. 2013 \\
\hline Bradyrhizobium & sp. & STM7333 & Piptadenia paniculata & Mimoseae & Brazil & - & 0 & Bournaud et al. 2013 \\
\hline Bradyrhizobium & sp. & STM7378 & Goldmania paraguensis & Mimoseae & Brazil & - & 0 & Bournaud et al. 2013 \\
\hline Paraburkholderia & caribensis & STM1423 & Dalbergia louveli & Dalbergieae & Madagascar & - & 0 & $\begin{array}{l}\text { Rasolomampianina } \\
\text { et al. } 2005\end{array}$ \\
\hline Paraburkholderia & caribensis & STM1424 & Dalbergia louveli & Dalbergieae & Madagascar & - & 0 & $\begin{array}{l}\text { Rasolomampianina } \\
\text { et al. } 2005\end{array}$ \\
\hline Paraburkholderia & caribensis & TJ183 & Mimosa pudica & Mimoseae & Taiwan & $\ldots$ & 1 & Chen et al. 2003a \\
\hline Paraburkholderia & diazotrophica & STM7399 & Anadenanthera peregrina & Mimoseae & Brazil & + & 1 & Bournaud et al. 2013 \\
\hline Paraburkholderia & diazotrophica & STM7439 & Anadenanthera colubrina & Mimoseae & Brazil & + & 1 & Bournaud et al. 2013 \\
\hline Paraburkholderia & mimosarum & PAS44T & Mimosa pigra & Mimoseae & Taiwan & $\ldots$ & 0 & Chen et al. 2006 \\
\hline Paraburkholderia & nodosa & JPY258 & Mimosa albolanata & Mimoseae & Brazil & $\ldots$ & 1 & Bontemps et al. 2010 \\
\hline Paraburkholderia & nodosa & JPY280 & Mimosa claussenii & Mimoseae & Brazil & $\ldots$ & 1 & Bontemps et al. 2010 \\
\hline Paraburkholderia & nodosa & JPY629 & Mimosa cyclophylla & Mimoseae & Brazil & $\ldots$ & 1 & Bontemps et al. 2010 \\
\hline Paraburkholderia & nodosa & STM7353 & Piptadenia trisperma & Mimoseae & Brazil & + & 1 & Bournaud et al. 2013 \\
\hline Paraburkholderia & nodosa & STM7363 & $\begin{array}{l}\text { Parapiptadenia } \\
\text { pterosperma }\end{array}$ & Mimoseae & Brazil & + & 1 & Bournaud et al. 2013 \\
\hline Paraburkholderia & phenoliruptrix & JPY580 & Mimosa cordistipula & Mimoseae & Brazil & $\ldots$ & 1 & Bontemps et al. 2010 \\
\hline Paraburkholderia & phenoliruptrix & JPY582 & Mimosa hexandra & Mimoseae & Brazil & $\ldots$ & 1 & Bontemps et al. 2010 \\
\hline Paraburkholderia & phenoliruptrix & STM7317 & Piptadenia gonocantha & Mimoseae & Brazil & + & 1 & Bournaud et al. 2013 \\
\hline Paraburkholderia & phenoliruptrix & STM7324 & Piptadenia paniculata & Mimoseae & Brazil & + & 1 & Bournaud et al. 2013 \\
\hline Paraburkholderia & phenoliruptrix & STM7415 & Anadenanthera peregrina & Mimoseae & Brazil & + & 1 & Bournaud et al. 2013 \\
\hline Paraburkholderia & phenoliruptrix & STM7454 & Anadenanthera colubrina & Mimoseae & Brazil & + & 1 & Bournaud et al. 2013 \\
\hline Paraburkholderia & phymatum & STM4206 & Mimosa pudica & Mimoseae & French Guiana & $\ldots$ & 1 & Mishra et al. 2012 \\
\hline Paraburkholderia & sabiae & STM7319 & Piptadenia gonocantha & Mimoseae & Brazil & + & 1 & Bournaud et al. 2013 \\
\hline Paraburkholderia & sabiae & STM7419 & Anadenanthera peregrina & Mimoseae & Brazil & + & 1 & Bournaud et al. 2013 \\
\hline Paraburkholderia & sp. & STM7296 & Piptadenia gonocantha & Mimoseae & Brazil & + & $1 *$ & Bournaud et al. 2013 \\
\hline Paraburkholderia & tuberum & JPY303 & Mimosa velloziana & Mimoseae & Brazil & $\ldots$ & 0 & Bontemps et al. 2010 \\
\hline Paraburkholderia & tuberum & JPY156 & $\begin{array}{l}\text { Mimosa setosa } \\
\text { var. paludosa }\end{array}$ & Mimoseae & Brazil & $\cdots$ & 0 & Bontemps et al. 2010 \\
\hline Paraburkholderia & tuberum & JPY158 & Mimosa pigra & Mimoseae & Brazil & $\ldots$ & 0 & Bontemps et al. 2010 \\
\hline Paraburkholderia & tuberum & JPY161 & Mimosa foliolosa & Mimoseae & Brazil & $\ldots$ & 0 & Bontemps et al. 2010 \\
\hline Paraburkholderia & tuberum & JPY623 & Mimosa radula & Mimoseae & Brazil & $\ldots$ & 0 & Bontemps et al. 2010 \\
\hline Paraburkholderia & tuberum & STM6020 & Mimosa pudica & Mimoseae & French Guiana & $\ldots$ & 1 & Mishra et al. 2012 \\
\hline Paraburkholderia & tuberum & STM678 & Aspalathus carnosa & Crotalarieae & South Africa & - & $0^{*}$ & Moulin et al. 2001 \\
\hline Cupriavidus & sp. & MAPUD 10.1 & Mimosa pudica & Mimoseae & Costa Rica & $\ldots$ & 1 & Andrus et al. 2012 \\
\hline Cupriavidus & sp. & UYMMa02A & Mimosa magentea & Mimoseae & Uruguay & $\ldots$ & $1 *$ & Iriarte et al. 2016 \\
\hline Cupriavidus & sp. & ip $2.35 / \mathrm{pp} 2.35$ & Mimosa diplotricha & Mimoseae & Philippines & $\ldots$ & 1 & Andrus et al. 2012 \\
\hline Cupriavidus & sp. & MYM 10 & Mimosa diplotricha & Mimoseae & Porto Rico & $\ldots$ & 1 & Andrus et al. 2012 \\
\hline Cupriavidus & sp. & pp 2.41 & Mimosa pudica & Mimoseae & Philippines & $\ldots$ & 1 & Andrus et al. 2012 \\
\hline Cupriavidus & sp. & pp 2.75 & Mimosa pudica & Mimoseae & Philippines & $\ldots$ & 1 & Andrus et al. 2012 \\
\hline Cupriavidus & sp. & SWF66194 & Mimosa pudica & Mimoseae & China & $\ldots$ & 1 & Liu et al. 2011 \\
\hline Cupriavidus & taiwanensis & STM6077 & Mimosa pudica & Mimoseae & New Caledonia & $\ldots$ & 1 & Klonowska et al. 2012 \\
\hline Cupriavidus & taiwanensis & STM6133 & Mimosa pudica & Mimoseae & New Caledonia & $\ldots$ & 1 & Klonowska et al. 2012 \\
\hline Ensifer & sp. & MH37.1 & Mimosa himalayana & Mimoseae & India & $\ldots$ & 0 & Gehlot et al. 2013 \\
\hline Ensifer & sp. & MHM12.2 & Mimosa hamata & Mimoseae & India & $\ldots$ & 0 & Gehlot et al. 2013 \\
\hline Mesorhizobium & chacoense & LMG $19008 \mathrm{~T}$ & Prosopis alba & Mimoseae & Argentina & - & 0 & Velazquez et al. 2001 \\
\hline Mesorhizobium & chacoense & LMG 19009 & Prosopis alba & Mimoseae & Argentina & - & 0 & Velazquez et al. 2001 \\
\hline Mesorhizobium & chacoense & STM7859 & Prosopis alba & Mimoseae & Argentina & - & 0 & Velazquez et al. 2001 \\
\hline Rhizobium & etli & TJ169 & Mimosa diplotricha & Mimoseae & Taiwan & $\ldots$ & 0 & Chen et al. 2003a \\
\hline Rhizobium & etli sv. mimosae & Mim-7-4 & Mimosa affinis & Mimoseae & Mexico & $\ldots$ & 1 & Wang et al. 1999 \\
\hline Rhizobium & freirei & PRF81 & Phaseolus vulgaris & Phaseolinae & Brazil & - & $1 * \S$ & Ormeño-Orrillo et al. 2012 \\
\hline Rhizobium & gallicum & UPRM8060 & Piptadenia flava & Mimoseae & Puerto Rico & - & 1 & Zurdo-Piñeiro et al. 2004 \\
\hline Rhizobium & gallicum sv. gallicum & $\mathrm{R} 602 \mathrm{~T}$ & Phaseolus vulgaris & Phaseolinae & France & - & $1 *$ & Geniaux et al. 1993 \\
\hline Rhizobium & giardinii sv. giardini & $\mathrm{H} 152 \mathrm{~T}$ & Phaseolus vulgaris & Phaseolinae & France & - & 0 & Amarger et al. 1997 \\
\hline Rhizobium & leucaenae & CFN299 & Phaseolus vulgaris & Phaseolinae & Mexico & - & $1 * \S$ & Ribeiro et al. 2012 \\
\hline Rhizobium & mesoamericanum & STM3629 & Mimosa pudica & Mimoseae & French Guiana & $\ldots$ & 1 & Mishra et al. 2012 \\
\hline Rhizobium & mesoamericanum & STM6135 & Mimosa pudica & Mimoseae & New Caledonia & $\ldots$ & 1 & Klonowska et al. 2012 \\
\hline Rhizobium & mesoamericanum & STM6161 & Mimosa pudica & Mimoseae & New Caledonia & $\ldots$ & 1 & Klonowska et al. 2012 \\
\hline Rhizobium & sp. & STM7330 & Piptadenia paniculata & Mimoseae & Brazil & - & 0 & Bournaud et al. 2013 \\
\hline Rhizobium & sp. & STM7379 & Mimosa foetidus & Mimoseae & Brazil & $\ldots$ & 0 & Bournaud et al. 2013 \\
\hline Rhizobium & sp. & STM7420 & Anadenanthera peregrina & Mimoseae & Brazil & - & 0 & Bournaud et al. 2013 \\
\hline Rhizobium & sp. & STM7426 & Anadenanthera peregrina & Mimoseae & Brazil & - & 0 & Bournaud et al. 2013 \\
\hline Rhizobium & sp. & TJ167 & Mimosa diplotricha & Mimoseae & Taiwan & $\ldots$ & 0 & Chen et al. 2003a \\
\hline Rhizobium & sp. & NGR181 & Mimosa invisa & Mimoseae & $\begin{array}{c}\text { Papua New } \\
\text { Guinea }\end{array}$ & $\ldots$ & 0 & Elliott et al. 2009 \\
\hline Rhizobium & tropici & CIAT 899 & Phaseolus vulgaris & Phaseolinae & Colombia & - & $1 * \S$ & Ormeño-Orrillo et al. 2012 \\
\hline Rhizobium & tropici & TJ172 & Mimosa diplotricha & Mimoseae & Taiwan & $\ldots$ & 1 & Chen et al. $2003 \mathrm{a}$ \\
\hline Rhizobium & tropici & UPRM8021 & Mimosa ceratonia & Mimoseae & Puerto Rico & $\ldots$ & 0 & Zurdo-Piñeiro et al. 2004 \\
\hline Sinorhizobium & arboris & LMG 14917 & Prosopis chilensis & Mimoseae & Kenya & - & 1 & Nick et al. 1999 \\
\hline Sinorhizobium & arboris & LMG 14919 & Prosopis chilensis & Mimoseae & Soudan & + & $1 *$ & Nick et al. 1999 \\
\hline Sinorhizobium & kostiense & LMG 19225 & Prosopis chilensis & Mimoseae & Soudan & - & 1 & Martens et al. 2008 \\
\hline
\end{tabular}

a The presence of noe $M$ was analyzed by PCR, except for strains labeled with an asterisk (*), where the presence or absence of $n o e M$ was evidenced by genome sequence analysis. Symbol: $\S$ indicates that the noeM sequence corresponds to a truncated gene. 
Further studies should confirm this hypothesis or assess which biochemical reaction is catalyzed by NoeM. NoeM, like NodC, is a transmembrane protein, while all other nodulation proteins involved in NFs synthesis are cytosolic. It has been proposed that the Nod proteins form a multienzyme complex anchored in the inner membrane via NodC, allowing NF assembly on the cytoplasmic face of the inner membrane (Mergaert et al. 1997). NoeM could be part of the NodC complex or of another enzyme complex anchored in the inner membrane via this protein.

NoeM appeared to have specialized in rhizobial symbiosis. A phylodistribution analysis revealed that $C$. taiwanensis NoeM homologs split into two groups of proteobacterial proteins based on their homology with the query protein. The first group exhibited less than $44 \%$ identity in amino acid sequence while the second group exhibited more than $70 \%$. Although homologs of the first group are distributed in rhizobial and nonrhizobial strains, homologs of the second group are only present in rhizobial species; specifically, species belonging to the genera Ensifer/Sinorhizobium, Mesorhizobium, Neorhizobium, and Rhizobium in $\alpha$-proteobacteria and Paraburkholderia, Trinickia, and Cupriavidus in $\beta$-proteaobacteria. In sequenced rhizobial genomes, noeM was found located in symbiotic plasmids downstream from a nod box, and sometimes clustered with other symbiotic (nod or nif/fix/fdx) genes. Moreover, in C. taiwanensis, $n o e M$ expression is induced by an $\operatorname{nod} A B C$-inducing flavonoid (luteolin) (Amadou et al. 2008) and is controlled by nodD. Notably, noeM, as nodB (Marchetti et al. 2011), is expressed all along the symbiosis, in bacteria colonizing the rhizosphere, infection sites, and infection threads as well as bacteroids. Expression in bacteroids was rarely observed in the rhizobiumlegume symbiosis (Schlaman et al. 1991). Thus, we assigned the term noe $M$ to these newly identified rhizobial genes that encode a protein involved in NF biosynthesis.

The specialization of a group of fatty acid hydroxylases into nod genes may have occurred in several steps (i.e., duplication of a gene of the fatty acid hydroxylase family, acquisition of biochemical activity on NFs if the original one did not possess it, and connection to the nodulation regulation pathway). noe $M$ genes may then have spread to various rhizobial branches of $\alpha$ and $\beta$-proteobacteria via horizontal gene transfer, resulting in incongruency between the taxonomical and noe $M$ gene trees (Fig. 5). Most nod genes are monophyletic and are thought to have originated from such functional divergence and horizontal transfer (Aoki et al. 2013; Persson et al. 2015).

The nod genes encoding enzymes involved in the modification of the NF core structure have been shown to contribute nodulation efficiency or host specificity (Perret et al. 2000). Indeed, the presence of some host-specific nod genes has been correlated to the legume host spectrum (Lorquin et al. 1997). Although hundreds of rhizobial genomes have been sequenced (Joint Genome Institute Genomes OnLine Database), we only found noeM in 120 rhizobial genomes of the Rhizobium, Sinorhizobium (Ensifer), Mesorhizobium, Neorhizobium, Paraburkholderia, Trinickia, and Cupriavidus genera, $75 \%$ of them corresponding to isolates of the Mimoseae tribe. Specifically, noe $M$ was identified in all Mimosa pudica isolates (this study) (Clerissi et al. 2018) and in all tested strains nodulating $M$. pudica, strongly suggesting that this gene plays a role in $M$. pudica symbiosis. Consistently, we found that it is required for optimal nodulation of $M$. pudica in C. taiwanensis because an noeM-deletion mutant had decreased nodulation competitiveness. Although noeM was not required for $M$. pudica nodulation in the laboratory, a role in nodulation efficiency may have a crucial impact in the field, where bacteria are in competition with many other rhizobia (Yates et al. 2011). However, the presence of a full-length noeM is not indicative of the capacity to nodulate $M$. pudica. This is the case of the Phaseolus symbiont $R$. gallicum sv. gallicum R602, which does not nodulate $M$. pudica, possesses noeM, and produces open-reduced NFs. The inability to nodulate $M$. pudica may be due to incompatibility factors such as secretion systems that prevent nodulation of some host plants (Nelson and Sadowsky 2015).

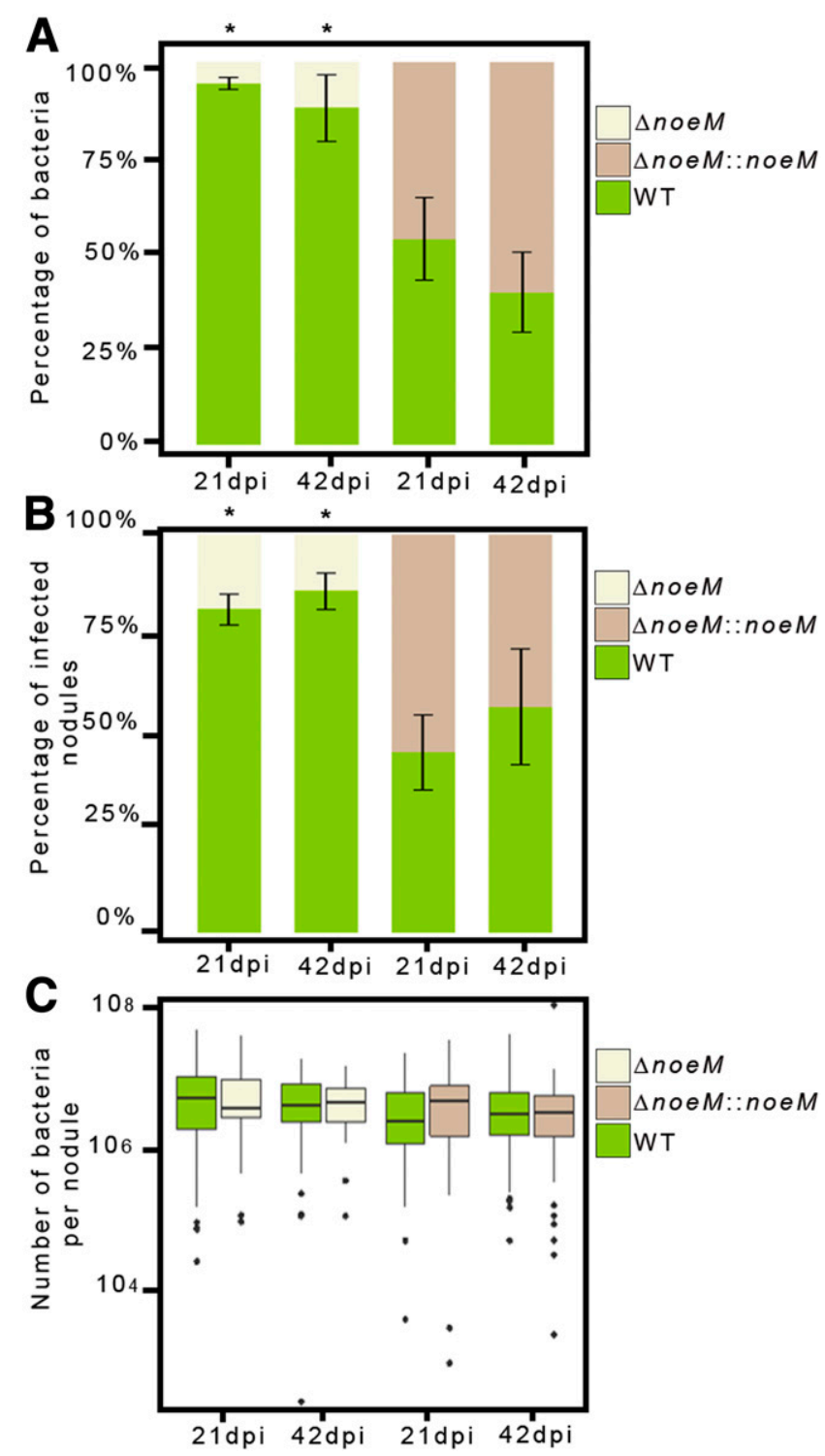

Fig. 7. Role of noeM in symbiosis with Mimosa pudica. M. pudica plantlets were coinoculated with a mix (1:1 ratio) of two Cupriavidus taiwanensis CBM832-derived strains, either wild-type green fluorescent protein (WTGFP)/AnoeM or WT-GFP/AnoeM::noeM. A, Relative in planta fitness; B, competitiveness for nodulation; and $\mathbf{C}$, nodule infection capacity were analyzed by plating bacterial populations of nodules individually collected at 21 and 42 days postinoculation (dpi). In $\mathrm{A}$ and $\mathrm{B}$, the percentage of bacteria or nodules is represented for each strain. Box plots in $\mathrm{C}$ represent the distribution of the number of bacteria recovered per nodule. Central rectangles span the first quartile to the third quartile (that is, the interquartile range), bold segments inside rectangles show the median, spots indicate suspected outliers, whiskers above and below the box show either the locations of the minimum and maximum in the absence of suspected outlying data. For the WT-GFP/AnoeM inoculum, 118 nodules were collected from 26 plants at 21 dpi and 136 nodules were collected from 23 plants at 42 dpi. For the WT-GFP/DnoeM::noeM inoculum, 121 nodules were collected from 23 plants at $21 \mathrm{dpi}$ and 197 nodules were collected from 24 plants at 42 dpi. Data were from three independent experiments. An asterisk $(*)$ indicates statistically significant difference between the two bacterial populations $(P<0.05$, Student's $t$ test with paired data at each time point for $\mathrm{A}$ and $\mathrm{B}$ and Wilcoxon rank sum test with continuity correction for C). 
Future studies should determine whether the production of open-oxidized NFs is a feature of $M$. pudica symbionts.

\section{MATERIALS AND METHODS}

Bacterial strains and growth conditions.

Strains and plasmids used in this study are listed in Table 3. C. taiwanensis strains were grown at $28^{\circ} \mathrm{C}$ on tryptone-yeast (TY) medium supplemented with $6 \mathrm{mM} \mathrm{CaCl} 2$ (Marchetti et al. 2010) or on minimal pseudo (MP) medium (Capela et al. 2017) supplemented with $10 \mathrm{mM}$ succinate (MPS). R. solanacearum strains were grown at $28^{\circ} \mathrm{C}$ on B medium supplemented with 28 $\mathrm{mM}$ glucose (Capela et al. 2017) or on MP medium (Capela et al. 2017) supplemented with $10 \mathrm{mM}$ glutamate. E. coli strains were grown at $37^{\circ} \mathrm{C}$ on Luria-Bertani medium. Antibiotics were used at the following concentrations: streptomycin at $200 \mu \mathrm{g} / \mathrm{ml}$, trimethoprim at $100 \mu \mathrm{g} / \mathrm{ml}$, tetracycline at $10 \mu \mathrm{g} / \mathrm{ml}$, chloramphenicol at $12.5 \mu \mathrm{g} / \mathrm{ml}$, carbenicillin at $50 \mu \mathrm{g} / \mathrm{ml}$, and kanamycin at $25 \mu \mathrm{g} / \mathrm{ml}$ (for E. coli) or $50 \mu \mathrm{g} / \mathrm{ml}$ (for R. solanacearum).

\section{Mutant construction.}

Primers used for mutant constructions are listed in Supplementary Table S3. Unlabeled noeM and nodD deletion mutants of $C$. taiwanensis CBM832 were constructed using the mutagenesis system developed by Flannagan et al. (2008), as described before (Daubech et al. 2017). Regions upstream and downstream from noeM were amplified with the oCBM3269oCBM3271 and oCBM3272-oCBM3274 primer pairs using GoTaq DNA polymerase (Promega Corp.). The two PCR products were digested with $\mathrm{XbaI}-B a m \mathrm{HI}$ and BamHI-EcoRI, respectively, and cloned into the pGPI-SceI plasmid digested by $X b a \mathrm{I}$ and EcoRI. Ligation products were transformed into a DH5 $\alpha \lambda$ pir E. coli strain. The resulting plasmid was transferred into CBM832 by triparental mating using pRK600 as helper plasmid. Deletion of nodD was performed in the same way, using the oCBM3365-oCBM3366 and oCBM3367-oCBM3368 primer pairs. Transconjugants that have integrated the plasmid by single crossing over were selected on streptomycin and trimethoprim and verified by PCR using the oCBM3315-oCBM3274 and oCBM3316-oCBM3269 primer pairs (noeM) or the primers oCBM3358-oCBM3368 and oCBM3363-oCBM3365 (nodD). The pDAI-SceI replicative plasmid was then introduced into these strains by conjugation using pRK2013 as helper plasmid and selected on tetracyclin. Expression of the I-SceI nuclease causes a double strand break into the inserted plasmid and promotes DNA recombination. Deleted mutants were screened for trimethoprim sensitivity and verified by PCR using the oCBM3315/oCBM3316 (noeM) or oCBM3358/oCBM3363 (nodD) primer pairs. Mutants

Table 3. Strains and plasmids used in this study

\begin{tabular}{|c|c|c|}
\hline Bacterium, plasmid & Relevant characteristics $^{\mathbf{a}}$ & Reference or source \\
\hline \multicolumn{3}{|l|}{ Escherichia coli } \\
\hline DH5 $\alpha$ & F recA lacZ M15, Car ${ }^{\mathrm{R}}$ & Bethesda Research Laboratory \\
\hline DH5 $\alpha \lambda$ pir & F recA lacZ M15 $\lambda$ pir, Tri ${ }^{\mathrm{R}}$ & HP Schweizer \\
\hline \multicolumn{3}{|l|}{ Cupriavidus taiwanensis } \\
\hline CBM832 & LMG19424 derivative, Str $^{R}$ & Marchetti et al. 2010 \\
\hline CBM2700 & $\begin{array}{l}\text { CBM832 carrying a } p s b A \text { promoter }(P p s) \text {-green fluorescent protein (GFP) } \\
\text { fusion downstream } g l m S, \mathrm{Str}^{\mathrm{R}}\end{array}$ & Daubech et al. 2017 \\
\hline CBM2708 & CBM832 carrying a Pps-mCherry fusion downstream $g \operatorname{lm} S, \mathrm{Str}^{\mathrm{R}}$ & Daubech et al. 2017 \\
\hline CBM2720 & $\begin{array}{l}\text { CBM832 carrying the nifH promoter region (PnifH) fused to mCherry } \\
\text { downstream } \operatorname{glm} S, \mathrm{Str}^{\mathrm{R}}\end{array}$ & This study \\
\hline CBM2856 & CBM832 carrying a 549-bp internal deletion in $n o e M, \mathrm{Str}^{\mathrm{R}}$ & This study \\
\hline CBM2858 & $\begin{array}{l}\text { CBM832 carrying a 404-bp DNA fragment upstream from noeM }(\text { PnoeM }) \text { fused } \\
\text { to mCherry downstream from } g \operatorname{lmS}, \mathrm{Str}^{\mathrm{R}}\end{array}$ & This study \\
\hline CBM2927 & CBM832 carrying a 642-bp internal deletion in $\operatorname{nodD}, \mathrm{Str}^{\mathrm{R}}$ & This study \\
\hline CBM2964 & $\begin{array}{l}\text { CBM2856 carrying a 234-bp DNA fragment including noeM and its promoter } \\
\text { region downstream from } \operatorname{glmS}, \mathrm{Str}^{\mathrm{R}}\end{array}$ & This study \\
\hline CBM2988 & $\begin{array}{l}\text { CBM2927 carrying a 404-bp DNA fragment PnoeM fused to mCherry } \\
\text { downstream from } g l m S, \mathrm{Str}^{\mathrm{R}}\end{array}$ & This study \\
\hline \multicolumn{3}{|c|}{ Rhizobium solanacearum } \\
\hline CBM124 & GMI1000 pRalta::Tri, Tri ${ }^{R}$ & Marchetti et al. 2010 \\
\hline CBM2689 & $\begin{array}{l}\text { CBM124 derivative carrying a 549-bp internal disruption by a kanamycin } \\
\text { cassette in } n o e M, \operatorname{Tri}^{\mathrm{R}}, \operatorname{Kan}^{\mathrm{R}}\end{array}$ & This study \\
\hline \multicolumn{3}{|c|}{ 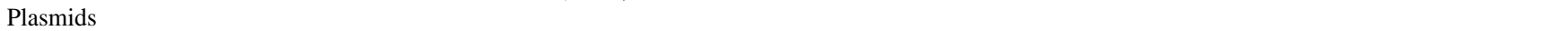 } \\
\hline pGEM-T & Cloning vector & Promega Corp. \\
\hline pGPI-SceI & ori $_{\mathrm{R} 6 \mathrm{~K}}, \mathrm{mob}^{+}$, carries an I-SceI site, $\mathrm{Tri}^{\mathrm{R}}$ & Flannagan et al. 2008 \\
\hline pDAI-SceI & ori $_{\mathrm{pBBR} 1}, \mathrm{mob}^{+}$, carries the I-SceI gene, $\mathrm{Tet}^{\mathrm{R}}$ & Flannagan et al. 2008 \\
\hline pCM162 & $\begin{array}{l}\text { pGPI-SceI carrying the } g \operatorname{lm} S \text {-Ralta_A0206 intergenic region interrupted by a } \\
\text { Pps-mCherry fusion, } \operatorname{Tri}^{\mathrm{R}}\end{array}$ & Daubech et al. 2017 \\
\hline pCM164 & $\begin{array}{l}\text { pGPI-SceI carrying the } g \operatorname{lmS} \text {-Ralta_A0206 intergenic region interrupted by an } \\
\text { nifH-mCherry fusion, } \mathrm{Tri}^{\mathrm{R}}\end{array}$ & This study \\
\hline pCBM197 & 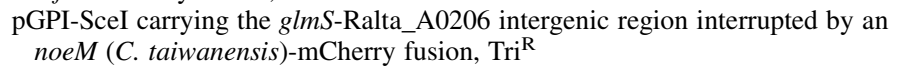 & This study \\
\hline pCBM198 & pGPI-SceI carrying the C. taiwanensis noeM $5^{\prime}$ and $3^{\prime}$ regions, $\operatorname{Tri}^{\mathrm{R}}$ & This study \\
\hline pCBM199 & pGPI-SceI carrying the $n o d D 5^{\prime}$ and $3^{\prime}$ regions, $\operatorname{Tri}^{\mathrm{R}}$ & This study \\
\hline pCBM201 & $\begin{array}{l}\text { pGPI-SceI carrying the glmS-Ralta_A0206 intergenic region interrupted by } \\
\text { noe } M \text { from } C \text {. taiwanensis and its promoter region, } \operatorname{Tri}^{\mathrm{R}}\end{array}$ & This study \\
\hline pCBM202 & $\begin{array}{l}\text { pGEM-T carrying carrying noeM from } C \text {. taiwanensis and a 404-bp DNA } \\
\text { fragment upstream from the gene }\end{array}$ & This study \\
\hline pRK600 & Helper plasmid, $\mathrm{Chl}^{\mathrm{R}}$ & Finan et al. 1986 \\
\hline pRK2013 & Helper plasmid, $\operatorname{Kan}^{\mathrm{R}}$ & Figurski and Helinski 1979 \\
\hline pJQ200 & ori $_{P 15 A}, \mathrm{mob}^{+}(\mathrm{RP} 4$ oriT $), \mathrm{Gm}^{\mathrm{R}}$, suicide plasmid & Quandt and Hynes 1993 \\
\hline
\end{tabular}


were cultivated on unselective TY medium and tetracyclinesensitive colonies having lost the pDAI-SceI plasmid were selected.

An unlabeled $C$. taiwanensis noeM mutant complemented with noeM was constructed by inserting a 1,234-bp DNA fragment including noeM and its 404-bp upstream region in the CBM2856 intergenic region between the glmS and RALTA_A0206 genes using the same pGPI-SceI/pDAI-SceI mutagenesis system described above. Regions upstream and downstream from noeM were amplified with oCBM3279-oCBM3430 using the phusion DNA polymerase (Thermo Fisher Scientific). The PCR products were digested with AvrII and SpeI, respectively, and cloned into pCM162 digested by AvrII and SpeI. Ligation products were transformed into a DH5 $\alpha \lambda$ pir E. coli strain and then transferred into $C$. taiwanensis CBM2856 by triparental mating using pRK600 as helper plasmid. Transconjugants were verified by PCR using the oCBM2739-oCBM3430 and oCBM3279-oCBM2740 primer pairs. Integration of the DNA fragment by crossing over was carried out using the pDAI-SceI plasmid as described above and verified by PCR using the oCBM2739-oCBM2740 primer pair.

The nifH-mCherry and noeM-mCherry fusions were inserted into the wild type and into the nodD mutant of $C$. taiwanensis at the same chromosomal locus (i.e., in the intergenic region between the $g \operatorname{lm} S$ and RALTA_A0206 genes using the same pGPI-SceI/pDAI-SceI mutagenesis system. The fusions were constructed using pCBM162 digested by EcoRI and SpeI. The promoter regions of noeM and nifH were amplified by PCR using the oCBM3279-oCBM3165 and the oCBM2617-oCBM2618 primer pairs, respectively. The PCR products were digested by EcoRI and SpeI and cloned in the digested pGPI, then inserted into the strains. Transconjugants were verified by PCR using the oCBM2739-oCBM2618/oCBM2617-oCBM2740 (nifHmCherry fusions) or the oCBM2739-oCBM3165/oCBM3279oCBM2740 (noeM-mCherry fusions) primer pairs. Integration of the DNA fragment by crossing over was carried out using the pDAI-SceI plasmid as described above and verified by PCR using the oCBM2739-oCBM2740 primer pair.

For the construction of the noeM deletion mutant of $R$. solanacearum CBM124, the $5^{\prime}$ and $3^{\prime}$ flanking regions were PCR amplified using the oCBM3388-oCBM3370 and oCBM3371-oCBM3372 primer pairs, respectively. The PCR products were digested with EcoRI/Acc65I and SacI/SacII, respectively, and cloned one after the other into pCM184 (Marx et al. 2002) digested with EcoRI/Acc65I and SacI/SacII. Ligation products were transformed into a DH5 $\alpha \lambda E$. coli strain. The plasmid was linearized with EcoRI and introduced into $R$. solanacearum CBM124 by natural transformation, as described by Capela et al. (2017). The transformants were selected on kanamycin and the construction was verified using the oCBM3315-oCBM3316 primer pair.

\section{NF purification and characterization.}

Strains were grown in minimal media overnight, then diluted to $\mathrm{OD}=0.1$ and cultivated for $5 \mathrm{~h}$, then diluted to $\mathrm{OD}=0.05$ in 1 liter of MPS and cultivated $2 \mathrm{~h}$ before adding $10 \mu \mathrm{M}$ luteolin. Cultures were grown for an additional $24 \mathrm{~h}$ and stopped at midexponential phase. Cultures were centrifuged at 3,500 rpm and supernatants extracted twice with 1-butanol. The organic fractions were pooled, washed with water, and vacuum dried. After dissolution in water and extraction with ethyl acetate, the fraction was dried again. The obtained residue was submitted to an SPE cleaning on a C18 5- $\mu \mathrm{m}$ reversed-phase stationary phase (Macherey and Nagel) conditioned with water. Three fractions were collected: the $20 \%$ acetonitrile (ACN) in water, $50 \% \mathrm{ACN}$ in water, and finally $100 \% \mathrm{ACN}$ elution. The fractions were then submitted to mass spectrometric analyses. The mass spectrometer was a QTrap4500 (AB Sciex) equipped with a UPLC device (Dionex Thermo Fisher Scientific). Analyses were performed in the less-selective positive mode. To increase the signal, enhanced mass spectra were acquired using the linear trap. MS/MS spectra were also acquired to assess the structure of the different compounds.

\section{Plant tests.}

M. pudica seed (B\&T World Seed) were sterilized as described (Chen et al. 2003b). Seedlings were cultivated in Gibson tubes, as previously described (Marchetti et al. 2014). Plantlets were inoculated with a single strain for nodulation kinetics $\left(0.5 \times 10^{6}\right.$ bacteria/plant $)$ or with a mixture of C. taiwanensis derivatives (GFP-labeled and unlabeled $\Delta$ noeM mutant, ratio $1: 1 ; 10^{6}$ total bacteria/tube) for in planta fitness, nodulation competitiveness, and nodule infection capacity analysis. Nodules of coinoculated plants were individually collected at 21 or $42 \mathrm{dpi}$, surface sterilized for $15 \mathrm{~min}$ in a $2.5 \%$ sodium hypochlorite solution, rinsed with water, and crushed. Each nodule crush was diluted in water and plated using an easy spiral automatic plater (Interscience). Green colonies (GFPlabeled strains) were counted after 2 days of incubation at $28^{\circ} \mathrm{C}$, under a fluorescence stereo zoom microscope (Axiozoom V16; Zeiss) when appropriate. From these data, we calculated the in planta fitness (total bacteria recovered divided by the number of total nodules), the nodulation competitiveness (number of nodules inhabited by a given strain divided by the number of total nodules), and the nodule infection capacity (number of bacterial cells per nodule inhabited by a given strain) for each inoculated strain.

To analyze the expression of noe $M$ during symbiosis, plants were grown on $12-\mathrm{cm}^{2}$ plates (three plants per plate) containing slanting nitrogen-free Fahraeus agar medium for 3 days at $28^{\circ} \mathrm{C}$. Roots were covered with a sterile, gas-permeable, and transparent plastic film (BioFolie 25; Sartorius AG, Vivascience). Plants were inoculated with $10^{7}$ mCherry-tagged bacteria per plant. Roots were collected at $24 \mathrm{~h}$ postinoculation and $7 \mathrm{dpi}$ and fixed in $3.2 \%$ paraformaldehyde. The fixed roots were observed using a confocal microscope (Confocal Leica SP8). Nodules were collected at $21 \mathrm{dpi}$ and cut for nodule sections $55 \mathrm{~mm}$ thick using a Leica VT1000S vibratome. Samples were observed by using a fluorescence microscope (Zeiss Axiophot).

\section{Quantitative RT-PCR.}

Bacteria were cultivated overnight in $30 \mathrm{ml}$ of MPS medium. Overnight cultures were diluted to OD $=0.1$ in $100 \mathrm{ml}$ of MPS and cultivated for additional $2 \mathrm{~h}$ at $28^{\circ} \mathrm{C}$. Cultures were then divided into two equal cultures of $50 \mathrm{ml}$, and luteolin $(10 \mu \mathrm{M}$ final concentration) or absolute ethanol was added. Cultures were harvested $5 \mathrm{~h} 30 \mathrm{~min}$ after luteolin induction by adding $1 / 10$ volume of cold phenol/ethanol (5:95) mixture, then centrifuged for $15 \mathrm{~min}$ at $4{ }^{\circ} \mathrm{C}$ at $4,000 \mathrm{rpm}$. The pellets were frozen in liquid nitrogen and stored at $-80^{\circ} \mathrm{C}$ until RNA extraction. For RNA extraction, pellets were resuspended in lysozyme at $1 \mathrm{mg} / \mathrm{ml}$ in Tris-EDTA (10:1, pH 8) buffer and incubated for $5 \mathrm{~min}$ at room temperature. A mirVana kit (Ambion) was used for the extraction of the RNAs. To remove residual genomic DNA, the RNAs were treated at $37^{\circ} \mathrm{C}$ for 30 min with Turbo DNase and purified with the Sureprep kit (Fisher BioReagents) twice. The quality of the extracted RNAs was assessed using a 2100 Bioanalyzer instrument (Agilent Technologies) and their concentration was determined using a Nanodrop ND 1000 spectrophotometer (ThermoFisher Scientific). For quantitative RT-PCR, $1 \mu \mathrm{g}$ of RNA was reverse transcribed using the Transcriptor Reverse Transcription kit (Roche, Life Technologies) and random hexamers as primers (Invitrogen). Real-time PCRs were run on a LightCycler system 
(Roche, Life Technologies) using the Eurogentec Takyon qPCR kit (Eurogentec). The hisB and $r p o A$ genes were used as reference genes. Primer pairs oCBM3812/foCBM3813 for hisB, oCBM3814/oCBM3815 for rpoA, oCBM1513/oCBM1514 for $n o d B$, and oCBM1515/oCBM1516 for noeM) were used for quantitative PCR.

\section{Quantification of the mCherry expression.}

Bacteria were cultivated overnight in MPS, diluted to OD = 0.05 , and cultivated for an additional $3 \mathrm{~h}$. Luteolin $(10 \mu \mathrm{M}$ final concentration) or the same volume of ethanol absolute was added and $200 \mu \mathrm{l}$ from each culture was distributed in triplicate on 96-well microplates. Fluorescence and growth were measured using The FLUOstar Omega (BMG LABTECH) over $24 \mathrm{~h}$.

\section{noeM homologs, symbiotic plasmids, and nod boxes.}

We searched for pRalta_0471 homologs in Refseq proteins using blastP (searched on 10 October 2018). We discarded hits with e-values $<10-5$, with $<40 \%$ identity in amino acid sequence, or aligning $<50 \%$ of the query protein. Conversely, homologous proteins were blasted against the $C$. taiwanensis proteome to identify bidirectional best hits $(\mathrm{BBH})$. BBH lacking stops and frameshifts and aligning $>70 \%$ of the query protein were defined as putative orthologs. Hits exhibiting $>70 \%$ identity in amino acid sequence and aligning $>70 \%$ of the query protein were defined as NoeM proteins. Plasmids were identified as symbiotic plasmids when they bore the common nodABC genes. For nod box prediction, $1 \mathrm{~kb}$ upstream from noe $M$ were extracted from genome sequences and the AT(N11)AT(N7)AT(N11)AT motif was searched using Patscan (Dsouza et al. 1997) and confirmed by expert examination. For the screening of the presence of noeM homologs in rhizobial strains, DNA was extracted using a quick Proteinase K method (Wilson 1987) and amplified using the primer pairs St_desF1 and St_desR2, which allowed the most efficient universal amplification of an internal noeM 650-bp sequence. PCR amplifications were performed with GoTaq DNA Polymerase (Promega Corp.) according to the manufacturer's instructions, and using $0.625 \mathrm{U}$ of GoTaq, $2.5 \mu \mathrm{mol}$ each dNTP, and $20 \mu \mathrm{mol}$ each primer in $25 \mu \mathrm{l}$ of volume reaction. PCR protocol included 1 min of initial DNA denaturation at $95^{\circ} \mathrm{C} ; 35$ cycles with $30 \mathrm{~s}$ of denaturation at $95^{\circ} \mathrm{C}, 30 \mathrm{~s}$ of hybridization at $55^{\circ} \mathrm{C}$, and $1 \mathrm{~min}$ of elongation at $72^{\circ} \mathrm{C}$; and a final step of $10 \mathrm{~min}$ at $72^{\circ} \mathrm{C}$. PCR amplification products were checked for purity by electrophoresis, and sent for sequencing with the St_desR2 primer.

\section{Alignment and phylogenetic analyses.}

The phylogenetic tree of NoeM protein sequences was built using the the MEGA X program (Kumar et al. 2018). Multiple alignment was performed using Muscle. The evolutionary history of sequences was inferred by using the maximumlikelihood method (Le and Gascuel 2008). The tree with the highest log likelihood $(-13,534.96)$ is shown. Initial trees for the heuristic search were obtained automatically by applying neighbor-joining and BioNJ algorithms to a matrix of pairwise distances estimated using a JTT model, then selecting the topology with superior log-likelihood value. The multiple sequence alignment of rhizobial NoeM was performed using Multalin, version 5.4.1.

\section{Statistical analyses.}

For the statistical analysis of the mCherry expression, growth curves were fitted to logistic equations using the $\mathrm{R}$ package GrowthCurver (version 0.3.0) to obtain interpretable metrics from microbial growth curves (Sprouffske and Wagner 2016). The area under the logistic curve (AUC), which provides a metric (the logistic AUC) that integrates information from the logistic parameters, was used in a two-way analysis of variance (ANOVA) examining the effect of the luteolin on $p s b A::$ $m$ Cherry and noeM::mCherry, taking into account biological repeats. Assumptions of the ANOVA were verified $(\alpha=0.05)$ using a Shapiro test for error normality distribution and a Bartlett test for error homoscedasticity. Post-hoc analyses were performed using the Tukey honestly significant difference test $(\alpha=0.05)$.

For the statistical analysis of the nodulation kinetics, the area under the curves of each experiment was calculated using the the $\mathrm{R}$ package agricolae (version1.3-1) and compared between strains using Student's test in R.

\section{ACKNOWLEDGMENTS}

We thank M. Parker, P. Young, E. James, and E. Martínez-Romero for providing rhizobial strains, P. Remigi and M.-F. Jardinaud for help in statistical analyses, and S. Fort, S. Cottaz, and A. Rousseau for helpful discussion.

\section{AUTHOR-RECOMMENDED INTERNET RESOURCE}

Joint Genome Institute Genomes OnLine Database: https://gold.jgi.doe.gov/

\section{LITERATURE CITED}

Althabegoiti, M. J., Ormeño-Orrillo, E., Lozano, L., Torres Tejerizo, G., Rogel, M. A., Mora, J., and Martínez-Romero, E. 2014. Characterization of Rhizobium grahamii extrachromosomal replicons and their transfer among rhizobia. BMC Microbiol. 14: Article 6.

Amadou, C., Pascal, G., Mangenot, S., Glew, M., Bontemps, C., Capela, D., Carrère, S., Cruveiller, S., Dossat, C., Lajus, A., Marchetti, M., Poinsot, V., Rouy, Z., Servin, B., Saad, M., Schenowitz, C., Barbe, V., Batut, J., Médigue, C., and Masson-Boivin, C. 2008. Genome sequence of the $\beta$-rhizobium Cupriavidus taiwanensis and comparative genomics of rhizobia. Genome Res. 18:1472-1483.

Amarger, N., Macheret, V., and Laguerre, G. 1997. Rhizobium gallicum sp. nov. and Rhizobium giardinii sp. nov., from Phaseolus vulgaris nodules. Int. J. Syst. Bacteriol. 47:996-1006.

Andrus, A. D., Andam, C., and Parker, M. A. 2012. American origin of Cupriavidus bacteria associated with invasive Mimosa legumes in the Philippines. FEMS Microbiol. Ecol. 80:747-750.

Aoki, S., Ito, M., and Iwasaki, W. 2013. From $\beta$ - to $\alpha$-proteobacteria: The origin and evolution of rhizobial nodulation genes nodIJ. Mol. Biol. Evol. 30:2494-2508

Bec-Ferté, M.-P., Krishnan, H. B., Savagnac, A., Pueppke, S. G., and Promé, J.-C. 1996. Rhizobium fredii synthesizes an array of lipooligosaccharides, including a novel compound with glucose inserted into the backbone of the molecule. FEBS Lett. 393:273-279.

Bontemps, C., Elliott, G. N., Simon, M. F., Dos Reis Júnior, F. B., Gross, E., Lawton, R. C., Neto, N. E., de Fátima Loureiro, M., De Faria, S. M., Sprent, J. I., James, E. K., and Young, J. P. W. 2010. Burkholderia species are ancient symbionts of legumes. Mol. Ecol. 19:44-52.

Bournaud, C., de Faria, S. M., dos Santos, J. M., Tisseyre, P., Silva, M., Chaintreuil, C., Gross, E., James, E. K., Prin, Y., and Moulin, L. 2013 Burkholderia species are the most common and preferred nodulating symbionts of the Piptadenia group (tribe Mimoseae). PLoS One 8:e63478

Broghammer, A., Krusell, L., Blaise, M., Sauer, J., Sullivan, J. T., Maolanon, N., Vinther, M., Lorentzen, A., Madsen, E. B., Jensen, K. J., Roepstorff, P., Thirup, S., Ronson, C. W., Thygesen, M. B., and Stougaard, J. 2012. Legume receptors perceive the rhizobial lipochitin oligosaccharide signal molecules by direct binding. Proc. Natl. Acad. Sci. U.S.A. 109:13859-13864.

Capela, D., Marchetti, M., Clérissi, C., Perrier, A., Guetta, D., Gris, C., Valls, M., Jauneau, A., Cruveiller, S., Rocha, E. P. C., and Masson-Boivin, C. 2017. Recruitment of a lineage-specific virulence regulatory pathway promotes intracellular infection by a plant pathogen experimentally evolved into a legume symbiont. Mol. Biol. Evol. 34:2503-2521.

Chen, W. M., James, E. K., Coenye, T., Chou, J. H., Barrios, E., de Faria, S. M., Elliott, G. N., Sheu, S. Y., Sprent, J. I., and Vandamme, P. 2006. Burkholderia mimosarum sp. nov., isolated from root nodules of Mimosa spp. from Taiwan and South America. Int. J. Syst. Evol. Microbiol. 56: 1847-1851 
Chen, W. M., James, E. K., Prescott, A. R., Kierans, M., and Sprent, J. I. 2003a. Nodulation of Mimosa spp. by the $\beta$-proteobacterium Ralstonia taiwanensis. Mol. Plant-Microbe Interact. 16:1051-1061.

Chen, W. M., Moulin, L., Bontemps, C., Vandamme, P., Béna, G., and Boivin-Masson, C. 2003b. Legume symbiotic nitrogen fixation by $\beta$-proteobacteria is widespread in nature. J. Bacteriol. 185:7266-7272.

Chen, X. C., Feng, J., Hou, B. H., Li, F. Q., Li, Q., and Hong, G. F. 2005. Modulating DNA bending affects NodD-mediated transcriptional control in Rhizobium leguminosarum. Nucleic Acids Res. 33:2540-2548.

Clerissi, C., Touchon, M., Capela, D., Tang, M. X., Cruveiller, S., Parker, M. A., Moulin, L., Masson-Boivin, C., and Rocha, E. P. C. 2018. Parallels between experimental and natural evolution of legume symbionts. Nat. Commun. 9: Article 2264.

Daubech, B., Remigi, P., Doin de Moura, G., Marchetti, M., Pouzet, C., Auriac, M. C., Gokhale, C. S., Masson-Boivin, C., and Capela, D. 2017. Spatio-temporal control of mutualism in legumes helps spread symbiotic nitrogen fixation. eLife 6:e28683.

D'Haeze, W., and Holsters, M. 2002. Nod factor structures, responses, and perception during initiation of nodule development. Glycobiology 12: 79R-105R.

Downie, J. A. 1998. Functions of rhizobial nodulation genes. Pages 387-402 in: The Rhizobiaceae. H. P. Spaink, A. Kondorosi, and P. J. J. Hooykaas, eds. Springer, Dordrecht, The Netherlands.

Dsouza, M., Larsen, N., and Overbeek, R. 1997. Searching for patterns in genomic data. Trends Genet. 13:497-498.

Elliott, G. N., Chou, J. H., Chen, W. M., Bloemberg, G. V., Bontemps, C., Martínez-Romero, E., Velázquez, E., Young, J. P. W., Sprent, J. I., and James, E. K. 2009. Burkholderia spp. are the most competitive symbionts of Mimosa, particularly under N-limited conditions. Environ. Microbiol. 11:762-778.

Figurski, D. H., and Helinski, D. R. 1979. Replication of an origincontaining derivative of plasmid RK2 dependent on a plasmid function provided in trans. Proc. Natl. Acad. Sci. U.S.A. 76:1648-1652.

Finan, T. M., Kunkel, B., De Vos, G. F., and Signer, E. R. 1986. Second symbiotic megaplasmid in Rhizobium meliloti carrying exopolysaccharide and thiamine synthesis genes. J. Bacteriol. 167:66-72.

Flannagan, R. S., Linn, T., and Valvano, M. A. 2008. A system for the construction of targeted unmarked gene deletions in the genus Burkholderia. Environ. Microbiol. 10:1652-1660.

Gehlot, H. S., Tak, N., Kaushik, M., Mitra, S., Chen, W. M., Poweleit, N., Panwar, D., Poonar, N., Parihar, R., Tak, A., Sankhla, I. S., Ojha, A., Rao, S. R., Simon, M. F., dos Reis Junior, F. B., Perigolo, N., Tripathi, A. K., Sprent, J. I., Young, J. P., James, E. K., and Gyaneshwar, P. 2013. An invasive Mimosa in India does not adopt the symbionts of its native relatives. Ann. Bot. 112:179-196.

Geniaux, E., Laguerre, G., and Amarger, N. 1993. Comparison of geographically distant populations of Rhizobium isolated from rootnodules of Phaseolus vulgaris. Mol. Ecol. 2:295-302.

Gough, C., and Cullimore, J. 2011. Lipo-chitooligosaccharide signaling in endosymbiotic plant-microbe interactions. Mol. Plant-Microbe Interact. 24:867-878.

Iriarte, A., Platero, R., Romero, V., Fabiano, E., and Sotelo-Silveira, J. R. 2016. Draft genome sequence of Cupriavidus UYMMa02A, a novel beta-Rhizobium species. Genome Announc. 4:e01258-16.

Kim, K. R., and Oh, D. K. 2013. Production of hydroxy fatty acids by microbial fatty acid-hydroxylation enzymes. Biotechnol. Adv. 31: 1473-1485.

Klonowska, A., Chaintreuil, C., Tisseyre, P., Miché, L., Melkonian, R., Ducousso, M., Laguerre, G., Brunel, B., and Moulin, L. 2012. Biodiversity of Mimosa pudica rhizobial symbionts (Cupriavidus taiwanensis, Rhizobium mesoamericanum) in New Caledonia and their adaptation to heavy metal-rich soils. FEMS Microbiol. Ecol. 81: 618-635.

Klonowska, A., Melkonian, R., Miché, L., Tisseyre, P., and Moulin, L. 2018. Transcriptomic profiling of Burkholderia phymatum STM815, Cupriavidus taiwanensis LMG19424 and Rhizobium mesoamericanum STM3625 in response to Mimosa pudica root exudates illuminates the molecular basis of their nodulation competitiveness and symbiotic evolutionary history. BMC Genomics 19: Article 105.

Kumar, S., Stecher, G., Li, M., Knyaz, C., and Tamura, K. 2018. MEGA X: Molecular evolutionary genetics analysis across computing platforms. Mol. Biol. Evol. 35:1547-1549.

Le, S. Q., and Gascuel, O. 2008. An improved general amino acid replacement matrix. Mol. Biol. Evol. 25:1307-1320.

Lerouge, P., Roche, P., Faucher, C., Maillet, F., Truchet, G., Promé, J. C., and Dénarié, J. 1990. Symbiotic host-specificity of Rhizobium meliloti is determined by a sulphated and acylated glucosamine oligosaccharide signal. Nature 344:781-784.
Liu, C.-W., and Murray, J. D. 2016. The role of flavonoids in nodulation host-range specificity: An update. Plants 5:33.

Liu, X. Y., Wu, W., Wang, E. T., Zhang, B., Macdermott, J., and Chen, W. X. 2011. Phylogenetic relationships and diversity of $\beta$-rhizobia associated with Mimosa species grown in Sishuangbanna, China. Int J. Syst. Evol. Microbiol. 61:334-342.

Lorquin, J., Lortet, G., Ferro, M., Mear, N., Dreyfus, B., Prome, J. C., and Boivin, C. 1997. Nod factors from Sinorhizobium saheli and S. teranga bv. sesbaniae are both arabinosylated and fucosylated, a structura feature specific to Sesbania rostrata symbionts. Mol. Plant-Microbe Interact. 10:879-890.

Madsen, E. B., Madsen, L. H., Radutoiu, S., Olbryt, M., Rakwalska, M., Szczyglowski, K., Sato, S., Kaneko, T., Tabata, S., Sandal, N., and Stougaard, J. 2003. A receptor kinase gene of the LysM type is involved in legume perception of rhizobial signals. Nature 425:637-640.

Marchetti, M., Capela, D., Glew, M., Cruveiller, S., Chane-Woon-Ming, B., Gris, C., Timmers, T., Poinsot, V., Gilbert, L. B., Heeb, P., Médigue, C., Batut, J., and Masson-Boivin, C. 2010. Experimental evolution of a plant pathogen into a legume symbiont. PLoS Biol. 8:e1000280.

Marchetti, M., Catrice, O., Batut, J., and Masson-Boivin, C. 2011. Cupriavidus taiwanensis bacteroids in Mimosa pudica Indeterminate nodules are not terminally differentiated. Appl. Environ. Microbiol. 77:2161-2164.

Marchetti, M., Jauneau, A., Capela, D., Remigi, P., Gris, C., Batut, J., and Masson-Boivin, C. 2014. Shaping bacterial symbiosis with legumes by experimental evolution. Mol. Plant-Microbe Interact. 27:956-964.

Martens, M., Dawyndt, P., Coopman, R., Gillis, M., De Vos, P., and Willems, A. 2008. Advantages of multilocus sequence analysis for taxonomic studies: A case study using 10 housekeeping genes in the genus Ensifer (including former Sinorhizobium). Int. J. Syst. Evol. Microbiol. 58:200-214.

Marx, C. J., and Lidstrom, M. E. 2002. Broad-host-range cre-lox system for antibiotic marker recycling in gram-negative bacteria. Biotechniques 33: 1062-1067.

Masson-Boivin, C., and Sachs, J. L. 2018. Symbiotic nitrogen fixation by rhizobia-the roots of a success story. Curr. Opin. Plant Biol. 44:7-15.

Mergaert, P., Van Montagu, M., and Holsters, M. 1997. Molecular mechanisms of Nod factor diversity. Mol. Microbiol. 25:811-817.

Mishra, R. P. N., Tisseyre, P., Melkonian, R., Chaintreuil, C., Miché, L., Klonowska, A., Gonzalez, S., Bena, G., Laguerre, G., and Moulin, L. 2012. Genetic diversity of Mimosa pudica rhizobial symbionts in soils of French Guiana: Investigating the origin and diversity of Burkholderia phymatum and other beta-rhizobia. FEMS Microbiol. Ecol. 79:487-503.

Moulin, L., Klonowska, A., Caroline, B., Booth, K., Vriezen, J. A. C., Melkonian, R., James, E. K., Young, J. P. W., Bena, G., Hauser, L., Land M., Kyrpides, N., Bruce, D., Chain, P., Copeland, A., Pitluck, S., Woyke, T., Lizotte-Waniewski, M., Bristow, J., and Riley, M. 2014. Complete genome sequence of Burkholderia phymatum STM815(T), a broad host range and efficient nitrogen-fixing symbiont of Mimosa species. Stand. Genomic Sci. 9:763-774.

Moulin, L., Mornico, D., Melkonian, R., and Klonowska, A. 2013. Draft genome sequence of Rhizobium mesoamericanum STM3625, a nitrogenfixing symbiont of Mimosa pudica isolated in French Guiana (South America). Genome Announc. 1:e00066-12.

Moulin, L., Munive, A., Dreyfus, B., and Boivin-Masson, C. 2001. Nodulation of legumes by members of the $\beta$-subclass of Proteobacteria. Nature 411:948-950.

Mulligan, J. T., and Long, S. R. 1985. Induction of Rhizobium meliloti nodC expression by plant exudate requires nodD. Proc. Natl. Acad. Sci. U.S.A. 82:6609-6613.

Nandasena, K. G., O’Hara, G. W., Tiwari, R. P., and Howieson, J. G. 2006. Rapid in situ evolution of nodulating strains for Biserrula pelecinus $\mathrm{L}$. through lateral transfer of a symbiosis island from the original mesorhizobial inoculant. Appl. Environ. Microbiol. 72:7365-7367.

Nelson, M. S., and Sadowsky, M. J. 2015. Secretion systems and signal exchange between nitrogen-fixing rhizobia and legumes. Front. Plan Sci. 6:491.

Nick, G., de Lajudie, P., Eardly, B. D., Suomalainen, S., Paulin, L., Zhang, X., Gillis, M., and Lindström, K. 1999. Sinorhizobium arboris sp. nov. and Sinorhizobium kostiense sp. nov., isolated from leguminous trees in Sudan and Kenya. Int. J. Syst. Bacteriol. 49:1359-1368

Oldroyd, G. E. D., and Downie, J. A. 2008. Coordinating nodule morphogenesis with rhizobial infection in legumes. Annu. Rev. Plant Biol. 59:519-546.

Oldroyd, G. E. D., Murray, J. D., Poole, P. S., and Downie, J. A. 2011. The rules of engagement in the legume-rhizobial symbiosis. Annu. Rev. Genet. 45:119-144.

Olsthoorn, M. M. A., López-Lara, I. M., Petersen, B. O., Bock, K., Haverkamp, J., Spaink, H. P., and Thomas-Oates, J. E. 1998. Novel 
branched nod factor structure results from $\alpha-(1 \rightarrow 3)$ fucosyl transferase activity: The major lipo-chitin oligosaccharides from Mesorhizobium loti strain NZP2213 bear an $\alpha-(1 \rightarrow 3)$ fucosyl substituent on a nonterminal backbone residue. Biochemistry 37:9024-9032.

Ormeño-Orrillo, E., Menna, P., Almeida, L. G. P., Ollero, F. J., Nicolás, M. F., Pains Rodrigues, E., Shigueyoshi Nakatani, A., Silva Batista, J. S., Oliveira Chueire, L. M., Souza, R. C., Ribeiro Vasconcelos, A. T., Megías, M., Hungria, M., and Martínez-Romero, E. 2012. Genomic basis of broad host range and environmental adaptability of Rhizobium tropici CIAT 899 and Rhizobium sp. PRF 81 which are used in inoculants for common bean (Phaseolus vulgaris L.). BMC Genomics 13: Article 735.

Peck, M. C., Fisher, R. F., and Long, S. R. 2006. Diverse flavonoids stimulate NodD1 binding to nod gene promoters in Sinorhizobium meliloti. J. Bacteriol. 188:5417-5427.

Perret, X., Staehelin, C., and Broughton, W. J. 2000. Molecular basis of symbiotic promiscuity. Microbiol. Mol. Biol. Rev. 64:180-201.

Persson, T., Battenberg, K., Demina, I. V., Vigil-Stenman, T., Vanden Heuvel, B., Pujic, P., Facciotti, M. T., Wilbanks, E. G., O’Brien, A., Fournier, P., Cruz Hernandez, M. A., Mendoza Herrera, A., Médigue, C., Normand, P., Pawlowski, K., and Berry, A. M. 2015. Candidatus Frankia Datiscae Dg1, the actinobacterial microsymbiont of Datisca glomerata, expresses the canonical nod genes nodABC in symbiosis with its host plant. PLoS One 10:e0127630.

Quandt, J., and Hynes, M. F. 1993. Versatile suicide vectors which allow direct selection for gene replacement in gram-negative bacteria. Gene 127:15-21.

Rasolomampianina, R., Bailly, X., Fetiarison, R., Rabevohitra, R., Béna, G., Ramaroson, L., Raherimandimby, M., Moulin, L., De Lajudie, P., Dreyfus, B., and Avarre, J. C. 2005. Nitrogen-fixing nodules from rose wood legume trees (Dalbergia spp.) endemic to Madagascar host seven different genera belonging to $\alpha$ - and $\beta$-proteobacteria. Mol. Ecol. 14: 4135-4146.

Remigi, P., Zhu, J., Young, J. P. W., and Masson-Boivin, C. 2016. Symbiosis within symbiosis: Evolving nitrogen-fixing legume symbionts. Trends Microbiol. 24:63-75.

Ribeiro, R. A., Rogel, M. A., López-López, A., Ormeño-Orrillo, E., Barcellos, F. G., Martínez, J., Thompson, F. L., Martínez-Romero, E., and Hungria, M. 2012. Reclassification of Rhizobium tropici type A strains as Rhizobium leucaenae sp. nov. Int. J. Syst. Evol. Microbiol. 62: 1179-1184.

Rostas, K., Kondorosi, E., Horvath, B., Simoncsits, A., and Kondorosi, A. 1986. Conservation of extended promoter regions of nodulation genes in Rhizobium. Proc. Natl. Acad. Sci. U.S.A. 83:1757-1761.

Schlaman, H. R. M., Horvath, B., Vijgenboom, E., Okker, R. J. H., and Lugtenberg, B. J. J. 1991. Suppression of nodulation gene expression in bacteroids of Rhizobium leguminosarum biovar viciae. J. Bacteriol. 173: 4277-4287.

Schultze, M., Quiclet-Sire, B., Kondorosi, E., Virelizer, H., Glushka, J. N., Endre, G., Géro, S. D., and Kondorosi, A. 1992. Rhizobium meliloti produces a family of sulfated lipooligosaccharides exhibiting different degrees of plant host specificity. Proc. Natl. Acad. Sci. U.S.A. 89: 192-196.
Shanklin, J., Whittle, E., and Fox, B. G. 1994. Eight histdine residues are catalitically essential in a membrane associated iron enzyme, stearoylCoA desaturase, and are conserved in alkane hydroxylase and xylene monooxygenase. Biochemistry 33:12787-12794.

Snoeck, C., Luyten, E., Poinsot, V., Savagnac, A., Vanderleyden, J., and Promé, J. C. 2001. Rhizobium sp. BR816 produces a complex mixture of known and novel lipochitooligosaccharide molecules. Mol. PlantMicrobe Interact. 14:678-684.

Soria-Díaz, M. E., Rodríguez-Carvajal, M. A., Tejero-Mateo, P., Espartero, J. L., Morón, B., Sousa, C., Megías, M., Thomas-Oates, J., and Gil-Serrano, A. M. 2006. Structural determination of the Nod factors produced by Rhizobium gallicum bv. gallicum R602. FEMS Microbiol. Lett. 255:164-173.

Sprouffske, K., and Wagner, A. 2016. Growthcurver: An R package for obtaining interpretable metrics from microbial growth curves. BMC Bioinf. 17: Article 172.

Sullivan, J. T., Patrick, H. N., Lowther, W. L., Scott, D. B., and Ronson, C. W. 1995. Nodulating strains of Rhizobium loti arise through chromosomal symbiotic gene transfer in the environment. Proc. Natl. Acad. Sci. U.S.A. 92:8985-8989.

Sullivan, J. T., and Ronson, C. W. 1998. Evolution of rhizobia by acquisition of a 500-kb symbiosis island that integrates into a phe-tRNA gene. Proc. Natl. Acad. Sci. U.S.A. 95:5145-5149.

Velázquez, E., Igual, J. M., Willems, A., Fernández, M. P., Muñoz, E., Mateos, P. F., Abril, A., Toro, N., Normand, P., Cervantes, E., Gillis, M., and Martínez-Molina, E. 2001. Mesorhizobium chacoense sp. nov., a novel species that nodulates Prosopis alba in the Chaco Arido region (Argentina). Int. J. Syst. Evol. Microbiol. 51:1011-1021.

Wang, E. T., Rogel, M. A., García-de los Santos, A., Martínez-Romero, J., Cevallos, M. A., and Martínez-Romero, E. 1999. Rhizobium etli bv. mimosae, a novel biovar isolated from Mimosa affinis. Int. J. Syst. Bacteriol. 49:1479-1491.

Wilson, K. 1987. Preparation of genomic DNA from bacteria. Pages 241-245 in: Current Protocols in Molecular Biology. F. M. Ausubel, R. Brent, R. E. Kingston, D. D. Moore, J. G. Seidman, J. A. Smith, and K. Struhl, eds. John Wiley \& Sons, New York, NY, U.S.A.

Yang, G. P., Debellé, F., Savagnac, A., Ferro, M., Schiltz, O., Maillet, F., Promé, D., Treilhou, M., Vialas, C., Lindstrom, K., Dénarié, J., and Promé, J. C. 1999. Structure of the Mesorhizobium huakuii and Rhizobium galegae Nod factors: A cluster of phylogenetically related legumes are nodulated by rhizobia producing Nod factors with $\alpha, \beta$-unsaturated $N$-acyl substitutions. Mol. Microbiol. 34: 227-237.

Yates, R. J., Howieson, J. G., Reeve, W. G., and O'Hara, G. W. 2011. A re-appraisal of the biology and terminology describing rhizobial strain success in nodule occupancy of legumes in agriculture. Plant Soil 348: 255-267.

Zurdo-Piñeiro, J. L., Velázquez, E., Lorite, M. J., Brelles-Mariño, G., Schröder, E. C., Bedmar, E. J., Mateos, P. F., and Martínez-Molina, E. 2004. Identification of fast-growing rhizobia nodulating tropical legumes from Puerto Rico as Rhizobium gallicum and Rhizobium tropici. Syst. Appl. Microbiol. 27:469-477. 